\title{
Biomarkers, Stem Cells and Esophageal Cancer
}

\author{
Irene Vegh and Ana I. Flores \\ Instituto de Investigación Hospital 12 de Octubre, Madrid, \\ Spain
}

\section{Introduction}

There are two main forms of esophagus cancer with different malignant behaviors: epidermal or squamous carcinoma (ESCC) and esophagus adenocarcinoma (EA). ESCC is associated with ethanol and tobacco consumption (tobacco-specific-N- nitroso compounds). ESCC is among the more aggressive cancers known. The high mortality rate associated with this type of cancer is directly related to a late diagnosis. Thus there is an important challenge to identify biomarkers for early diagnosis (Shimada et al., 2003; Sobin \& Fleming, 1997).

EA starts from a metaplasia mucosa-dysplasia-carcinoma sequence in the distal esophagus (Barrett's esophagus (BE), as a result of local injury and is associated with risk of malignant transformation. Cellular proliferation takes place through the subsequent phases of the cell cycle. During the cell cycle, there are different check points and, the transition from G1 to $S$ phase is the most studied in neoplastic progression of Barrett's cells and alterations in growth factor expression. Its receptors and/or the signal transduction pathways have been found at various stages during the progression of metaplasia to EA (Lao-Sirieix et al., 2007; Lord et al., 2000). BE is clinically important because the risk of progressing to adenocarcinoma under the chronically damaging effect of gastrointestinal reflux. EA of the upper esophagus is rare and in some cases develops from areas of gastric heterotopias. It has been hypothesized that intestinal metaplasia could have a change in their differentiation pattern. Indeed, a clonal selection model suggests that malignant transformation occurs by multiple allelic alterations (Nowell, 1976; Souza et al., 2008).

The incidence of EA has increased in the last 40 years. However, the biology of both, the normal esophageal epithelium and the pathogenesis involved in the development of esophageal cancer are not well understood. Epithelial changes are due to stimulation of esophageal stem cells of the epithelium. These changes in the activity of the esophagus stem cells and the up- or down-regulation of stem cell markers appear to be related in the pathogenesis of esophageal cancer and final clinical outcome. Over the last 5 years, important progress has been made in the identification and understanding of adult gastrointestinal stem cells. However, esophageal stem cells are not well characterized. Isolation and characterization of adult esophageal stem cells and the factors that contribute to the development of dysplasia and malignancy is a very important issue for the development of efficient therapies for esophageal cancer (Adams and Strasser, 2008; Croagh 
et al., 2008; Hormi-Carver and Souza, 2009). The clonal selection theory was thought to be responsible for the development of gastrointestinal cancers, based on the evidence that some cells acquire genetic alterations giving them the capacity of self-renewal (Adams and Strasser, 2008). Recently, the cancer stem cell (CSC) theory has gained more attention based on the idea that some cancers are initiated by stem cells with genetic alterations. Cellular and tissue regeneration is based on the characteristics of self-renewal and multipotency of stem cells. In recent years, progress in stem cell identification and characterization indicate their potential therapeutic applications in regenerative medicine for the treatment of several pathologies. The different types of stem cells, embryonic, induced pluripotent and adult stem cells are emerging as a potential approach to treat gastrointestinal disorders.

\section{Biomarkers or bio-indicators}

The so called tumor markers and biological markers are usually used in place of each other. Initially, tumor markers were developed and used to detect some mucin antigens on the cancer cell surface and/or in the serum of cancer patients. Those tumor markers on the cell surface that form glyco-conjugates are involved in adhesion, motility and metastasis. The tumor markers can induce the immune response early during malignant transformation, and later are shed by cancer cells into blood vessels and detected in serum or plasma. The ideal tumor marker have to be specific for malignant cells, detectable early in the carcinogenesis process, measurable by simple invasive methods and the concentrations measured have to be proportional to the stage of malignancy and/or a pharmacological response to therapeutic intervention. There are different tumor markers, each indicative of a particular disease process and used in oncology to detect the presence of a cancer. Tumor markers can be produced by the tumor cells or by the non-tumor cells as a response to the presence of a disease. This was used for identification, evaluation and follows up of treatment, either for patients based or population based and even experimental condition. Brief descriptions for it were focused on these tumor markers in different cancer types. The carcinoembrionary antigen CEA, is a glycoprotein involved in cell adhesion that was studied in lung carcinoma (Vegh et al., 2002) and colorectal carcinoma (Vegh et al., 2007). Cancer antigen 125 (CA 125) was used principally for screening ovarian cancer (Frederick et al., 2011). CA 19.9, also called carbohydrate antigen 19-9 was detected in colorectal carcinoma (Morales-Gutierrez et al., 1999; Vegh et al., 2003). Alpha fetoprotein (AFP) levels were increased in hepatocellular carcinoma and esophagus carcinoma (Bellet et al., 1984). Beta human chorionic gonadotropin ( $\beta \mathrm{HCC}$ ) was evaluated in different diseases (BurgKurland et al., 1989). Carbohydrate antigen 15.3 (CA 15.3) was mostly studied in breast carcinoma (Bearz et al., 2007). Some epidemiologic studies observed that the incidence for EA in all races had variations according to this histology, age and gender. There is a striking male predominance in esophageal cancer. Sex hormones have been suggested as a contributing factor and these are influenced by histology, age and race. The highest sex ratios were seen in esophagus EA in the age group between 50-59 years old, rendering plausibility to the hypothesis that female sex hormone exposure may play a protective role in the development of this type of cancer (Nordenstedt et al., 2011).

Nowadays, biomarkers or bio-indicators in cell biology are molecules that allow the detection and isolation of a particular cell type. In genetics, a biomarker is a DNA sequence that causes or is associated with the development of diseases. Biomarkers are used to 
indicate the variation in the expression of a characteristic protein that correlates with the risk of development of pathology. Currently, most biomarkers used in clinic are proteins, while based on genetics they might be DNA or RNA and they could also be subject of determination or application in clinic, specially in case of viral infected or DNA or RNA which are shed from individual tumor tissue stream. The expression of several biomarkers in plasma and tissue from patients with esophagus cancer were analyzed, and looked for the biomarkers whose over-expression could be associated with a different behavior in esophagus cancer and could have potential prognostic implications.

In this chapter our aim was to discuss each specific biomarker in separate sections in the context of esophageal cancer, as some of these markers are also important in the development and evolution of other types of tumors.

\subsection{Metalloproteinase}

The extracellular matrix (ECM) is the extracellular part of a tissue which provides support to cells and is known as connective tissue (Bosman and Stamenkovic, 2003). ECM includes the interstitial matrix and the basement membrane. EMC is composed of a variety of proteins and glycoaminoglicans. Numerous families of enzymes (proteinases) are responsible for the degradation of ECM. The family of enzymes called matrix metalloproteinases (MMPs) are the major enzymes implicated in extracellular degradation and are essential for embryonic development, morphogenesis, remodeling and tissue repair. MMPs are classified into five classes: collagenases (MMP-1,-8 and -13), gelatinases (MMP-2 and -9), stromelysins (MMP-3 and -10), membrane type matrilysins (MMP-7 and -26) and others. The MMPs are zincdependent endo-peptidases and are inhibited by specific endogenous inhibitors, the tissue inhibitor of metalloproteinases (TIMP). This MMPs family currently includes more than 26 members. Proteases not only have cell-matrix interaction, but also can control the progression of angiogenesis by activating growth factors such as hepatocyte growth factor (HGF), basic fibroblast growth factor (bFGF) and vascular endothelial growth factor (VEGF) and can influence cellular behavior. MMPs can act also as an inhibitor of angiogenesis. The data indicate that proteases can acts either as positive or negative regulators of angiogenesis (Brooks et al., 1998). MMP-1 is an interstitial collagenase secreted from fibroblasts, macrophages and keratocytes. MMP-1 is related to cancer aggressiveness and its expression is associated with a multistep carcinogenesis from BE to EA according to the clonal selection model (Etoh et al., 2000; Grimm et al., 2010). MMP-7 (matrilysin) is the smallest molecule of the MMPs, whose function is to degrade elastin, proteoglycans, fibronectin and type IV collagen. It has been found that MMP-7 was over-expressed in a variety of epithelial and mesenchymal tumors such as esophagus, colon, liver, renal, and pancreas. Increased circulating levels of MMP-7 proteins were correlated with the presence of metastatic disease and poor patient survival in colorectal and renal cell cancer (Maurel et al., 2007; Szarvas et al., 2010; Yamamoto et al., 1999; Yamashita et al., 2000). Some authors concluded that the autoantibody levels of MMP-7 in serum may be a good biomarker for ESCC (J.H. Zhou et al., 2011). Some pharmacologic studies designed various MMP inhibitors with poor effect probably due to their high toxicity as has been demonstrated in clinical trials.

TIMPs (tissue inhibitor of metalloproteinases) comprise a family of four protease inhibitors: TIMP-1 (chromosome Xp11.3-p11.23); TIMP-2 (chromosome 17q25); TIMP-3 (chromosome 
22q12.3); TIMP4 (chromosome 3q25). The first TIMP was described in 1975 as a protein which was able to inhibit collagenase activity (Bauer et al., 1975; Bosman and Stamenkovic, 2003). TIMPs and MMPs are found in all fluids, such as serum, plasma, urine, etc. All MMPs are inhibited by TIMPs once they are activated. The balance between MMPs and TIMPs plays a necessary role in maintaining the integrity of healthy tissue. An alteration of this balance is observed in different diseases. In cancer and rheumatoid arthritis, the imbalance is generally in favor of MMPs. By contrast to inhibition of MMPs by TIMPs, some studies founded that TIMP-2 was implicated in the activation of pro-MMP-2. This mechanism stimulates cell migration and progression to tumor metastasis and invasion (Yoshizuki et al., 2001). TIMPs are co-expressed with MMPs which depend on endogenously expressed growth factors and cytokines (Gomez et al., 1997).

The balance between MMPs and TIMPs is variable in both, in physiological processes such as growth and development, and in some diseases such as cancer. In esophagus cancer, we studied MMP-1 concentration in tumor and in non-tumor areas from the same patient with EA and observed a higher concentration in tumor areas (Vegh et al., 2007). Moreover, MMP1 was associated with poor clinical outcome in esophageal cancer in different studies (Etoh et al., 2000; Murray et al., 1998; Yamashita et al., 2001). We found similar results in the concentration of MMP-1 in tumor vs. non-tumor areas in patients who had ESCC, but without being associated with the clinicopathological outcome (Vegh et al., 2007). On the other hand, we have observed that TIMP-1 expression in esophagus cancer showed higher values in tumor areas (Vegh et al., 2007). Interestingly, the same patients with lymph node negative showed higher values on TIMP-1 expression, whereas patients with more than three positive lymph nodes had lower values. This profile could indicate an inhibitory function for TIMP-1 on tumor growth and its possible dissemination. Numerous researchers considered that TIMP-1 has mitogenic activity on different cell types, whereas its overexpression reduced tumor growth in gastric carcinoma (Mimori et al., 1997). Furthermore, studies focusing on nitric oxide (NO) showed enhanced expression of MMP-1,-3,-7 and TIMP-1 in the progression from non-dysplasic BE to adenocarcinoma. This could indicate that NO play a role in Barrett's carcinogenesis through deregulating of MMP and TIMP expression to enhance invasive potential in dysplasic cells (Clemons et al., 2010). MMP-7 was cloned from ESCC tissues and higher levels were observed in serum in patients with ESCC than in their matched-control samples, therefore it was considered that MMP-7 may be a good diagnostic biomarker for ESCC (J.H. Zhou et al., 2011).

\subsection{Polymorphisms and mutations}

It has been well established that cancer is a genetic disease and carcinogenesis takes place in somatic mutations of the oncogenes or tumor suppressor genes. There have been several studies showing that BE and EA can occur within families indicating an inherent genetic risk (Eng et al., 1993; Romero et al., 1997). A pivotal role corresponds to phosphatidylinositol 3-kinase (PIK3CA) signaling pathway. In vitro ESCC proliferation was reduced by a PIK3CA inhibitor. This inhibition has more effects on the cells that contain a PIK3CA gene mutation than those without such mutation (Mori et al., 2008). It has also been speculated that some polymorphisms affecting the inflammatory response might be important in esophageal carcinoma. Such approaches may allow the identification of subsets of individuals within a population who are predisposed to EA. Accumulation of genetic 
alterations follows the dysplasia-adenocarcinoma sequence in the esophagus and identifies the patients with poor prognosis (Wu et al., 1998). The human genome receives exogenous and endogenous attacks that could promote genetic mutations, chromosomal rearrangements and finally development of cancer. Cells have an anti-DNA-damaging system to blockade both metabolic and external sources of DNA damaging agents. Activation of cell cycle checkpoints and DNA repair system are complex processes which help cellular responses to DNA damage. These checkpoints generally stop cell-cycle progression at the G1, S, and G2 phases. Gamma-radiation can induce single and double strand breaks. Some chemical carcinogenetic compounds, such as benzo(a) pyrene-diolepoxide a tobacco procarcinogen benzo(a) pyrene, form bulky adducts and need nucleotide excision pathways to remove the adducts. Deficiencies in cell cycle checkpoint pathways are more frequently observed in esophagus cancer than in healthy donors. Shao et al, 2006 compared the mutagen-induced damage level among individuals with different S or G2-M phase cell accumulation and observed an increase of esophageal cancer risk.

\subsection{Oncogen p53}

Oncogen p53 is a major regulator of the cell response to stress and acts as a tumor suppressor by inducing cell cycle arrest or apoptosis. Inactivation of the p53 signaling pathway has been seen in different human cancers. Previously, polymorphisms of p53 have been reported to be a possible risk factor for some types of tumors (Hrstka et al., 2009; Levine et al., 2004; Wu et al., 1998). The most common polymorphism on $p 53$ is at the $72^{\text {nd }}$ amino acid residue with an arginine (Arg) to proline (Pro) change because of a $\mathrm{G} \rightarrow \mathrm{C}$ transverse. Differences in the biochemical or biological characteristics of the wild type $p 53$ variants have been reported. Some authors considered that the Arg72 variant can better induce apoptosis than the Pro72, indicating that the two polymorphic variants of p53 (also so called TP53) are functionally distinct, which may influence cancer risk and treatment (Matlashewski et al., 1987; Thomas et al., 1999; Whibley et al., 2009). Numerous studies have reported this $p 53$ polymorphism in several cancers such as cervical, lung, breast, and gastric cancer (Dai et al., 2009; Dumont et al., 2003; Z. Zhang et al., 2011; Zhou et al., 2007), but its association with esophagus cancer remains elusive. Several specific molecular alterations play crucial roles in esophagus cancer, with tumor cell aneuploidy and p53 mutations being major hallmarks of both ESCC and EA (Blant et al., 2001; Fang et al., 2004; Jiang et al., 2010; Kuwano et al., 2005; Minu et al., 1994; Montesano et al., 1996; Souza, 2010; Whibley et al., 2009; Yu et al., 2007). Levine et al., 1991 considered that alteration or inactivation of p53 by mutations or interaction with oncogene products of DNA tumor viruses can lead to cancer. However, some researchers found no association between the immunomarkers p53, cyclin D1 and bcl-2 with the clinicopathological data and outcome in a selected population of esophagogastric junction adenocarcinoma patients (Lehrbach et al., 2009). The 17p is the chromosomial locus for $p 53$ oncogene. Studies of allelic alterations on chromosome 17p.13 and in 17p11.2-22 (microsatellite region adjacent to the p53 locus) were performed by polymerase chain reaction (PCR) using two different primers (D17S513 and D17S514), (Table 1). An allelic alteration was observed in both tumor and non-tumor areas of esophagus cancer patients. Moreover, this dinucleotide repeat polymorphism was observed in both EA and ESCC. In addition, our studies showed statistically significant high levels of MMP-1 associated with this allelic alteration in the EA group. In the ESCC group, the allelic alteration was found associated with positive lymph nodes (Vegh et al., 2007). 


\begin{tabular}{|c|c|c|c|c|c|}
\hline Biomarker & $\begin{array}{l}\text { Patients } \\
\text { (n) }\end{array}$ & Values expressed & $\mathrm{P}$ & $\begin{array}{l}\text { Overall } \\
\text { survival time }\end{array}$ & References \\
\hline $\begin{array}{l}\text { CNR-1 gene } \\
\text { (controls) }\end{array}$ & 40 & $\begin{array}{l}\text { G/G: } 60.0 \% \\
\text { G/A: } 40.0 \% \\
\text { A/A: } 0.0 \%\end{array}$ & & ND & \\
\hline CNR-1 gene; (EC) & 29 & $\begin{array}{l}\text { G/G: } 10.8 \% \\
\text { G/A: } 61.2 \% \\
\text { A/A: } 7.9 \% \\
\text { No a. } 20.1 \%\end{array}$ & & $\begin{array}{l}\text { G/G: } 56.3 \\
\text { months versus } \\
\text { A/A: } 3.5 \\
\text { months } \\
P=0.04\end{array}$ & $\begin{array}{l}\text { Bedoya et } \\
\text { al. 2009a }\end{array}$ \\
\hline $\begin{array}{l}\text { P53 (D17S513) } \\
\text { A/A type, EA }\end{array}$ & 23 & a.a.: $69.9 \%$ & & ND & \\
\hline $\begin{array}{l}\text { P53 (D17S514) } \\
\text { A/A type, EA }\end{array}$ & 23 & a.a.: $82.6 \%$ & & ND & $\begin{array}{l}\text { Vegh et al. } \\
2007\end{array}$ \\
\hline $\begin{array}{l}\text { P53 (D17S513) } \\
\text { A/A type, ESCC }\end{array}$ & 14 & a.a.: $50.0 \%$ & & ND & \\
\hline $\begin{array}{l}\text { P53 (D17S514) } \\
\text { A/ A type, ESCC }\end{array}$ & 14 & a.a.: $78.6 \%$ & & ND & $\begin{array}{l}\text { Vegh et al. } \\
2007\end{array}$ \\
\hline VEGF tumor & 39 & $300.6 \pm 99.7 \mathrm{pg} / \mathrm{mg}$ & \multirow[b]{2}{*}{$<0.025$} & \multirow[b]{2}{*}{$\mathrm{P}=0.11$} & \\
\hline VEGF no tumor & 100 & $80.8 \pm 19.7 \mathrm{pg} / \mathrm{mg}$ & & & $\begin{array}{l}\text { Bedoya et } \\
\text { al. 2009a }\end{array}$ \\
\hline MMP1 (EA) & 23 & $45.6 \pm 7.6 \mathrm{ng} / \mathrm{mg}$ & \multirow[b]{2}{*}{$<0.05$} & \multirow[b]{2}{*}{ ND } & \multirow[b]{2}{*}{$\begin{array}{c}\text { Vegh et al. } \\
2007\end{array}$} \\
\hline TIMP1 (EA) & 23 & $28.7 \pm 7.0 \mathrm{ng} / \mathrm{mg}$ & & & \\
\hline MMP1 (ESCC) & 14 & $37.0 \pm 6.9 \mathrm{ng} / \mathrm{mg}$ & \multirow[b]{2}{*}{$=0.44$} & \multirow[b]{2}{*}{ ND } & \multirow[b]{2}{*}{$\begin{array}{l}\text { Vegh et al. } \\
2007\end{array}$} \\
\hline TIMP1 (ESCC) & 14 & $38.9 \pm 7.5 \mathrm{ng} / \mathrm{mg}$ & & & \\
\hline
\end{tabular}

EC: esophageal cancer; VEGF: vascular endothelial growth factor; CNR1 gene: cannabinoid receptor 1 gene; G/G wild type, G/A heterozygous mutation; A/A homozygous mutation; P53: oncogene p53; D17S513 and D17S514: primers used; a.a.: with allelic alterations; MMP1: Matrix metalloproteinase, TIMP: Tissue inhibitor metalloproteinase; ND: no data; No a.: with no amplification; EA: esophagus adenocarcinoma; ESCC: esophagus squamous cell carcinoma; vs.: versus; P minor than 0.05 was considered statistically significant.

Table 1. Biomarkers in esophagus cancer: Analysis data of different markers in tissue of esophagus cancer patients, according our some experiences.

DNA repair inhibitors are used by the cells to protect or reverse themselves against mutagens and different carcinogens. Some authors considered the small cyclin dependent kinase-inhibiting protein p21 as a critical mediator of $p 53$ function and required for $p 53$ mediated growth suppression of tumor cells (Waldman T et al., 1995). 


\subsection{Cannabinoids receptors and esophagus cancer}

The CB1 receptor (or CNR1) is encoded by the CNR1 gene and located in chromosome 6q14q15 (size 26,056 bases). CNR1 molecular function corresponds to a receptor activity and their biological processes such as signal transduction and G-protein signaling-coupled with a cyclic nucleotide second messenger (cyclic AMP). CNR1 is expressed most widely in the brain. Endocannabinoids (anandamine and 2-arachidonylglycerol) released from the neurons bind to $\mathrm{CBN1}$ receptors in the pre-synaptic neurons and produce a reduction in the release of the inhibitory neurotransmitter gamma-aminobutiric acid (GABA). Cannabinoid receptors are expressed on several cell types and have functions in liver, endocrine glands, on gastrointestinal and cardiovascular activity and on pain transmission. Endocannabinoids are agonists of cannabinoid receptors and have been shown to participate in the inhibition of malignant cells, in the proliferation of cancer tissues and have been associated with different stages of the disease (Pertwee, 1997). After the receptor is engaged, multiple intracellular signal transduction pathways are activated implicating potassium ion channels, calcium channels, protein kinase A and C, Raf-1, ERK, JNK, p38, c-fos, c-jun, etc. Previously, one simple nucleotide polymorphism (SNP) was detected at nucleotide positive $1359 \mathrm{G} \rightarrow \mathrm{A}$. Due to the high polymorphism information content, this SNP is considered as a useful intragenic marker which may be related to cannabinoid system alterations. The artificial creation of an $\mathrm{Mspl}$ restriction site in amplified wild type (G-allele) which is destroyed by the mutation (A-allele) has been useful to detect a silent mutation (Gadzicki et al., 1999). We have observed in CNR-1gene $10.8 \%$ of wild type in esophagus tissue samples of esophagus cancer patients as compared to $60.0 \%$ in CNR-1gene in control patients (Figure 1). We

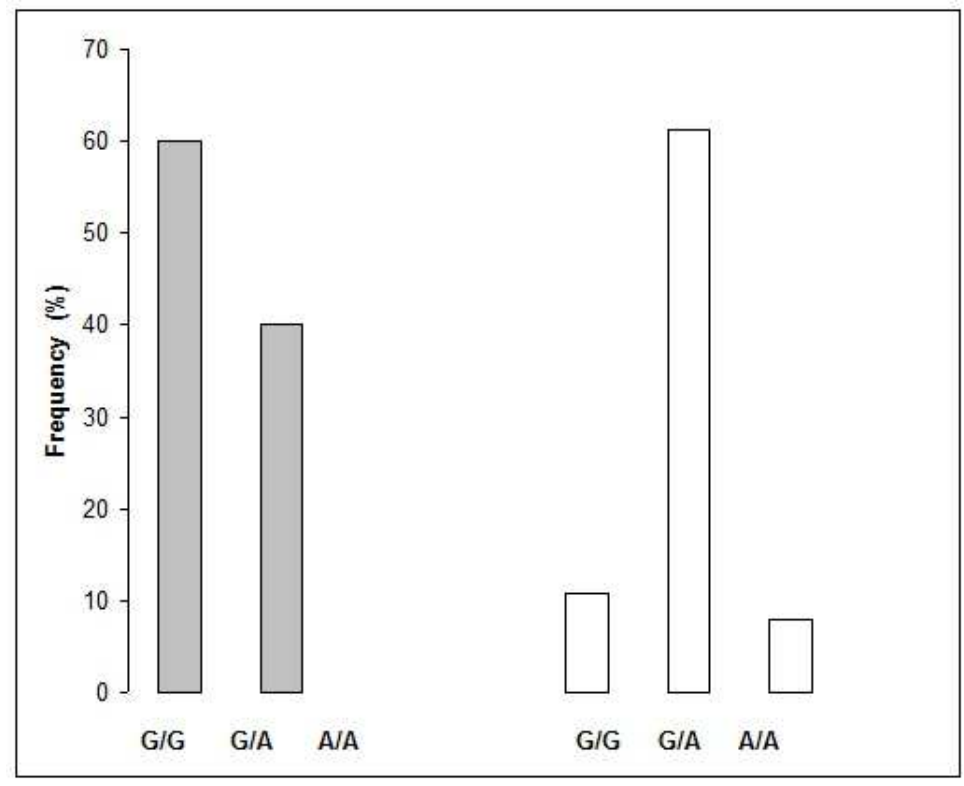

Fig. 1. Frequency of CNR1 gene expression in esophageal tissue. Grey bars, corresponding to control healthy patients $(n=40)$ esophagus tissue, no A/A mutation was observed. White bars, corresponding to CNR1gene expression in tumor of esophagus cancer patients $(n=29)$. 
concluded that this alteration may be considered as a mutation and hypothesized that this mutation is an acquired somatic mutation. Moreover, we also found that the mean survival time in wild type $G / G$ group was longer than $A / A$ homozygous group, $(P=0.04$, chi-square: 4.26) (Table 1). However, we did not find any association of CNR-1 with the angiogenic growth factor VEGF levels. However, VEGF expression was higher in tumor than in notumor $(\mathrm{P}<0.025)$, but VEGF expression did not correlate with survival time. (Bedoya et al., 2009a). So, we can consider that CNR1 gene could be considered an independent marker for survival. In addition, in colorectal cancer patients we have also found that CNR1 gene genotype G/A plus A/A group of patients has a shorter overall survival time than G/G wild type patients (Bedoya et al., 2009b).

\subsection{Vascular endothelial growth factor}

In carcinogenesis, genetic and epigenetic changes are important for malignant transformation. The growth of solid tumors which is regulated partly by the angiogenesis process and vascular endothelial growth factor (VEGF) has been identified as the principal regulator of angiogenesis in both, physiological and pathological conditions (Ferrara, et al., 1997; Folkman, 1990). VEGF's function is to create new blood vessels during embryonic development. Binding of VEGF and other ligands to the VEGF-receptor (VEGFR) of endothelial cells activates the angiogenic pathways. VEGF is strongly expressed in many human cancers, including esophageal carcinomas (Inoue et al., 1997) and intestinal cancers (Bendardaf et al., 2008). High levels of VEGF have been associated with a poor prognosis in cancer patients. Our studies did not observe any statistically significant differences in plasma VEGF concentration in esophageal cancer patients at different clinical stages neither did in samples corresponding to different tumor and not tumor areas (Figure 2). In this study we assayed in plasma VEGF concentration of control healthy and esophagus cancer patients and the difference was not statistically significant. Analyses of VEGF expression in tumor homogenate of these patients using a cut-off level of $120 \mathrm{pg} / \mathrm{mg}$ of total protein did not appear to correlate with the overall survival time (Bedoya et al., 2009a). However, high hypoxia-inducible transcription factor-1 (HIF-1) is an important inducer of angiogenesis and VEGF expression is important as a prognostic factor and related to survival in ESCC patients (Kimura et al., 2004). Moreover, some authors considered that these factors could help to predict the response of the ESCC patients to several therapies (Shimada et al., 2002). The role of other angiogenic factors such as transforming growth factor- $\alpha$ (TGF- $\alpha$ ) and basic fibroblast growth factor (bFGF) were studied by Li et al, 2000. They suggested that TGF- $\alpha$ as well as VEGF, PD-ECGF and bFGF may be associated with angiogenesis, and progression to metastases of ESCC patients. The diagnostic of lymph node status in esophagus cancer is a very important prognostic factor. VEGF-C is a potential angiogenic factor in lymph-nodes and selectively induces vasculature in the lymphatic glands. The expression of VEGF-C has a high correlation with the lymph node metastasis in patients with stage Tis and T1 of esophagus cancer patients (Tanaka et al., 2010).

\subsection{Epidermal growth factor receptor}

Epidermal growth factor (EGF) plays an important role in the cell cycle and may regulate the production of MMPs via over-expression of the epidermal growth factor receptor (EGFR). EGF protein was discovered by Stanley Cohen and Rita Levi-Montachini and both 
won the Nobel Prize in 1986. EGF is a low molecular -weight polypeptide of 6045-Da protein. EGF includes different biological processes such as the activation of MAPKK activity, DNA replication, chromosome organization, EGFR signaling pathway and interaction with phosphatidylinosidol 3-kinase complex (PIK3R2). EGFR are on the cell surface and are activated by binding with its specific ligands (EGF, TGFa and others). Upon activation, EGFR undergoes a transition from an inactive to an active form. The EGFR dimerization stimulates its intrinsic intracellular protein-tyrosine kinase activity. Mutations that induce EGFR over-expression have been associated with cancer. These mutations have been the target of several treatments allowing the development of anticancer therapies such as gefitinib and erlotinib for lung cancer, cetuximab and panitumumab for colorectal cancer, as examples of a monoclonal antibody acting as inhibitors of tyrosine kinase proteins. Indeed, without kinase activity, EGFR is inactive and does not initiate the signaling cascade

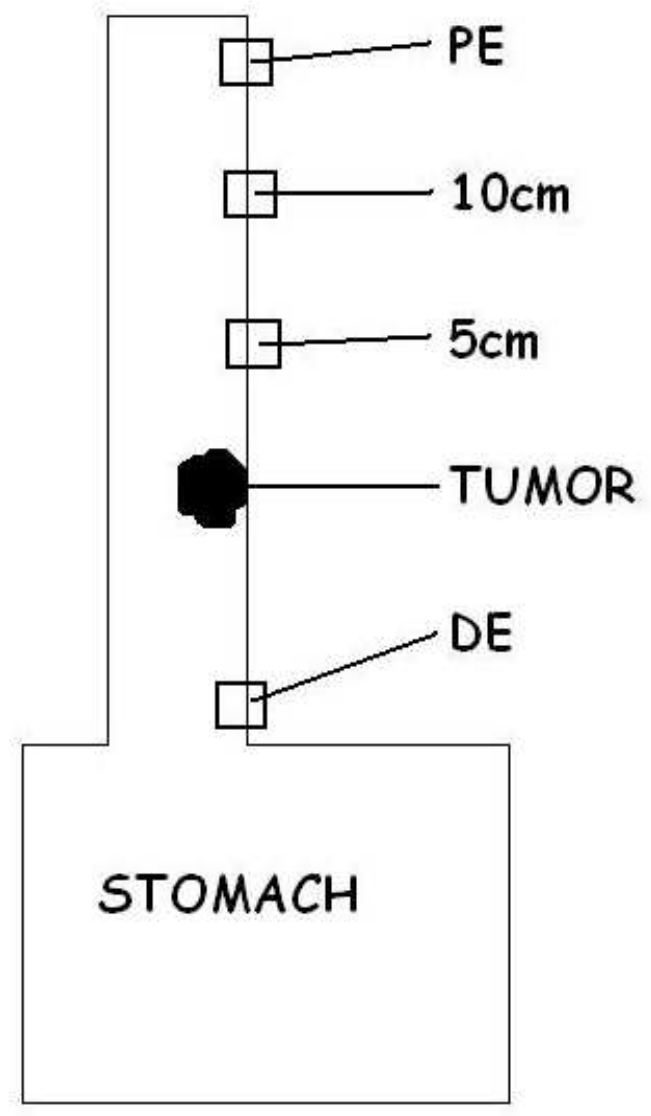

Fig. 2. Diagram of esophagus areas studied. PE: proximal edge of sample exceresis, $10 \mathrm{~cm}$ : sample from around tumor area; 5 com: sample around tumor area; T: tumor (EA or ESCC according to histopathologic diagnosis), DE: distal edge, sample obtained near to stomach. 
pathway for growth in the cells (Lynch et al., 2004). Several studies have demonstrated that EGFR is over-expressed in tumors and ESCC cell lines. However, immunohistochemical evaluation of EGFR did not provide prognostic information for ESCC patients (Torzewski et a.l, 1997). The fact that EGFR correlated with age, depth of invasion, lymph node metastasis and poor prognosis was observed (Inada et al., 1999). Our results have found the overexpression of EGFR in membrane of tumor homogenate in a group of esophageal cancer patients with more than three positive lymph nodes. Nevertheless, we did not find any significant differences between mean levels of EGFR in both tumor and non-tumor areas of the esophagus (Vegh et al., 2007). EGFR over-expression and mutant $p 53$ tumor suppressor genes help the enrichment of a cellular subpopulation involved in epithelial to mesenchymal transition among telomerase- immortalized human esophageal epithelial cells during carcinogenesis (Ohashi et al., 2010).

\subsection{Human chorionic gonadotropin-beta}

The human chorionic gonadotropin $(\beta \mathrm{HCG})$ is a glycoprotein synthesized by normal placenta and released by the trophoblastic cells and different neoplastic cells. In esophageal tumors, by immunostaining procedures Burg-Kurland et al., 1989 observed a variation in the staining intensity of the tumor cells. Cells were weakly stained in well differentiated squamous cell carcinomas, although the poorly differentiated cells showed a more generalized pattern of staining. Moreover, these studies considered that $\beta \mathrm{HCG}$ is associated with ESCC as well as EA and to pre-neoplastic lesions (Burg-Kurland et al., 1989). The characteristics of this tumor marker permit the monitoring and evaluation of the treatments.

\subsection{Carcinoembryonic antigen}

In 1965 Gold and coworkers demonstrated tumor-associated antigens in adenocarcinoma of the digestive tract in humans. The oncofetal carcinoembryonic antigen (CEA) is a glycoprotein with a molecular weight of $200,000 \mathrm{kDa}$ originally isolated in colon carcinoma cells and is located on the luminal surface of the tumor cell membrane of endodermal as well as non-endodermal origin. CEA expression in serum of esophagus cancer patients is not well recognized as a biomarker. Nevertheless, correlation between CEA levels in serum and tissue was observed in patients with esophagus cancer (Sanders et al., 1994); and elevated serum CEA levels were useful for early detection of relapse in patients with EA (Kim et al., 1995). We have reported that in tissue homogenate of EA patients there were not statistically significant differences in mean levels of CEA in tumor areas when compared with non-tumor (Vegh et al., 2007). However, in ESCC tumors, CEA concentration showed statistically significant higher values in tumor samples from patients with negative lymph nodes. These results were similar to those observed in nonsmall-cell lung cancer patients (Vegh et al., 2002). Kosugi et al., 2004 determined the role of preoperative serum levels of CEA, CA19-9 and SSC in patients with esophagus cancer. They found that only preoperative high levels of serum SCC antigen indicate an adverse outcome after esophagectomy and the appearance of distant metastases (Kijima et al., 2000; Kosugi et al., 2004). In summary, the CEA marker is very useful for monitoring previously diagnosed cancer. 


\subsection{Interleukins}

Interleukins (IL-1 through IL-17) are a group of cytokines that participate in stimulating the immune response in inflammation and in hematopoiesis. Interleukins are a group of cellular messenger molecules, so called cytokines, which act as modulators of cellular behavior and are secreted rapidly by cells in response to several stimuli such as an infectious agent. The first interleukin was identified in the 1970s (Gillis et al., 1978). Different types of interleukins have become known since then and are designated numerically. IL1 and IL2 are responsible for activating T and B lymphocytes. IL-1, along with IL-6, is also a mediator of inflammation. IL-6 expression at local tumor sites or in systemic circulation has been associated with disease progression and poor prognosis of esophageal cancer and may act as a resistance factor against cisplatin-based treatments (Suchi et al., 2011). The clinicopathological significance of IL-6 and other cytokine levels in esophageal cancer was associated with a poor outcome (Motoyama et al., 2011; Xin et al., 2010; H.Y. Zhang et al., 2011).

\subsection{0 microRNAs}

The expression of the miR-17-92 cluster was first shown in ESCC and is over-expressed in $75 \%$ of esophageal cancer patients (Liu et al., 2011). In addition, its over-expression could promote cellular growth in vivo and in vitro. Furthermore, antisense oligonucleotides (ONs) inhibited miR-19a and induced apoptosis while miR-17-5p, miR-18a, miR-20a and miR-92-1 were not affected. It was found that antagomir-19a treatment could impair tumor growth in vivo. In fact, using Human Apoptosis RT2 Profiler PCR Array 384HT was observed that tumor necrosis factor-a (TNF-a) was 12-fold up-regulated in cells transfected with miR-19a antisense ONs compared to the cells treated with the control scramble ONs. miR-19a was predicted to target the 3' untranslated region of TNF- $\alpha$ mRNA and this was confirmed by luciferase reporter assay. Taken together, they conclude that the miR-17-92 cluster is overexpressed in ESCC and that TNF-a could be a novel target of miR-19a (Liu et al., 2011).

\subsection{1 c-erbB-2 or HER2 gene}

HER-2/neu (c-erbB-2, HER2) gene amplification and protein over-expression have been associated with poor prognosis in several solid tumors, including breast and gastric cancer. However, its incidence and significance in EA is unknown (Thompson et al, 2011). Expression of erb-B2 in esophageal cancer patients was associated with longer survival and may be a good marker to monitoring the treatment sensitivity (D'Amico and Harpole, 2000).

\subsection{TGF-alpha}

Transforming growth factor-alpha (TGF-a) is produced by several human carcinomas. TGFa maps to human chromosome 2p11-2p13. TGF-a is a small protein of 50 amino acids. This growth factor is found in plasma and urine and is produced by some non-transformed cells during the development such as, keratocytes, macrophages, platelets and hepatocytes. Their synthesis is induced by estrogens and is related to EGF. The biological activities of both growth factors are very similar and both bind to the same membrane receptor encoded by the cellular erb oncogene. Experimental studies in Wistar rats observed that TGF- $\alpha$ and EGFR play crucial roles in chronic reflux esophagitis (Fujiwara et al., 2004). The integrity of 
esophageal mucosa, acts upon the equilibrium between cellular protective mechanisms and different aggressive factors. It has been found that human esophageal submucosal glands elaborate protective biomarkers like TGF-a, EGF, prostaglandin E(2), bicarbonate and nobicarbonate buffers (Sarosiek and McCallium, 2000). Nevertheless, an increased production of TGF- $\alpha$ is associated with malignant transformation in different cell types ( $\mathrm{Li}$ et al., 2000). TGF- $a$ can be assayed in plasma by a specific radioligant assay or the ELISA method and by colony formation assay. Aloia et al., 2001, analyzed the expression of the tumor markers Pgp, p53, and TGF-a in node-negative esophagus cancer patients. Their results showed that this type of analysis sustains the immunohistochemical prognostic value.

\subsection{TGF-beta}

Transforming growth factor beta (TGF- $\beta$ ) and Notch signaling pathways play important roles in regulating self-renewal of stem cells and cell-fate determination. Both pathways are frequently implicated in gastrointestinal carcinogenesis. TGF- $\beta 1$ mediated the mesenchymal-epithelial transition and may be relevant in esophageal carcinogenesis (Rees et al., 2006; Thiery, 2002). However, others showed that the contribution of TGF-beta to esophageal adenocarcinoma remains associated with EGFR and p53 (Ohashi et al, 2010). It is well known that the stromal compartment plays an important role in carcinogenesis. Genetic analysis showed a strong contribution of an inflammatory component and the key pathways included cytokine-cytokine receptor interactions and TGF- $\beta$ in BE disease progression and how these can affect the outcome or progression (Saadi et al. 2010).

\subsection{Alpha fetoprotein}

Alpha fetoprotein (AFP) is a glycoprotein of 591 aminoacids and a carbohydrate moiety. AFP is highly expressed in human fetus but in adults, AFP levels are low with unknown function, although it can be used as a biomarker to detect tumors. It is indicative of germcell tumors, hepatocellular carcinoma and ectopic production of AFP has also been found in different tumors. In some tumors, the decrease of AFP levels indicates a good prognostic value. AFP expression is elevated in gastrointestinal malignancies and its expression is related to metastasis (Liu et al., 2010; Mizejewski, 2002). In summary, this tumor marker is very useful for monitoring previously diagnosed cancer.

\subsection{CA 19-9}

The carbohydrate antigen 19-9 (CA 19-9) tumor marker can be detected in blood serum and in the tumor homogenate of different cancer patients. Levels are often elevated in some gastrointestinal cancers, such as colorectal, pancreatic and esophagus cancer. As previously reported by our group, the level CA 19-9 was detected by ELISA in colorectal cancer patients and was considered as an independent prognostic factor for the relapse (MoralesGutierrez et al, 1999). Studies performed in serum of human ESCC patients showed that CA19-9 is a link for E-selectin and this association may play an important role in tumor metastasis. Serum CA19-9 may be useful in the follow-up of recurrence and response to treatment (Mcknight et al, 1989; Oshiba et al, 2000). In EA patients, we observed a higher concentration of CA 19-9 in tumor areas than in non-tumor areas from the same patient, but these results did not correlate with their clinical characteristics (Vegh et al, 2007). 
Nevertheless, CA 19-9 concentration was higher in patients with more than three positive lymph nodes than in patients with negative nodes. In ESCC patients, CA 19-9 concentration did not show any differences between tumor and non-tumor areas. In conclusion, patients who had advanced or metastatic cancer can be monitored by their CA 19-9 levels throughout the treatment.

\subsection{Tumor Necrosis Factor $-\alpha$}

Tumor necrosis factor alpha (TNF-a) is a pro-inflammatory cytokine with conflicting effects in both, tumor growth and tumor regression. These paradoxical results seem to be related to differences in this cytokine concentration, as high therapeutic doses induced tumor regression while physiological levels of endogenous TNF-a promote tumor growth (Anderson et al., 2004). Clinical data related to TNF-a expression by esophageal cells are limited. Kilic et al. 2009, studied TNF-a and IL-2 expression in the distal esophageal muscle in patients with achalasia of the esophagus and observed that the proportion of inflammatory cells expressing TNF- $\alpha$ is inversely correlated with the duration of the clinical symptoms. Other studies have shown that TNF-a is up-regulated in the progression to Barret's metaplasia suggesting a role of TNF-a in the transcription of gastrointestinal oncogenes (Tselepsis et al., 2002). In ESCC where the miR-17-92 cluster is over-expressed, TNF-a seems to be a novel target of miR-19a (Liu et al., 2011).

\section{Esophageal cancer and stem cells}

Despite the fact the incidence of EA has increased over the last 40 years, the biology of the normal esophageal epithelium and the pathogenesis of esophageal cancer is not well understood (Nguyen et al., 2011). Currently, it is still unknown if esophageal cancer initiation, growth and maintenance is caused: i) by the "clonal selection theory", i.e., through the accumulation of genetic alterations in some cells that acquire growth advantage over normal cells and leads to the selection of these clones; ii) by the "cancer stem cell (CSC) theory" based in the suggestion that only a small number of stem cells accumulate the genetic alterations and contribute to the esophageal tumor growth and maintenance; or iii) by a mixture of both models (Adams and Strasser, 2008; Hormi-Carver and Souza, 2009).

\subsection{Cancer Stem Cell (CSC) theory and esophageal cancer}

CSC theory is based on the idea that most cancers are initiated for stem cells with genetic alterations that are unable to undergo terminal differentiation, i.e., the proliferation capacity of stem cells can be difficult to control under certain circumstances and contribute to the tumor formation (Nguyen et al., 2011; Quante and Wang, 2009). In solid tumors including esophageal cancer, the CSCs have been correlated with resistance to chemotherapy and radiation, recurrence and metastasis (Zhang et al., 2005). It is interesting to highlight the lack of agreement on the best markers for CSCs in digestive tumors and doubts about the real phenotype and also the existence of the CSCs (Quante and Wang, 2009). There is little evidence for the existence of CSCs in esophageal cancer. Stimulation of esophageal stem cells of the epithelium contributes to both, esophageal epithelial regeneration and cancer. Changes in the activity of the esophagus stem cells and the up- or down-regulation of stem cell markers appear to be related to esophageal cancer development, tumor progression and 
final clinical outcome. Further understanding and characterization of adult esophageal stem cells and the factors that contribute to the development of dysplasia and malignancy it is a matter of critical importance (Croagh et al., 2008).

\subsection{Stem cells in the esophagus}

Stem cells are classified in two general groups as embryonic and adult stem cells. They have the ability to regenerate the tissue where they reside because of their characteristics of selfrenewal and multipotency. Adult stem cells within the gastrointestinal tissue are classified as esophageal, gastric, intestinal, colonic, hepatic and pancreatic (Quante and Wang, 2009).

Stem cells in the human esophagus are present in the basal layer of the stratified squamous epithelium (Kalabis et al., 2008; Seery and Watt, 2000). Human esophagus is a complex tissue with a slow cell turnover (Croagh et al., 2008). A population of stem cells known as Side Population cells (SP cells) were isolated from mouse esophagus (Epperly et al., 2004; Kalabis et al., 2008). Esophageal SP cells have the ability to home in on and differentiate to esophagus cells as shown by in vitro and in vivo esophageal injury models. A rare stem cell population expressing high levels of $a_{6}$-integrin and low levels of CD71 was characterized in the basal layer of the mouse esophagus and whose final function is to form and/or regenerate the suprabasal layers (Croagh et al., 2007). A population of stem cells characterized by low expression of $\beta 1$-integrin and high expression of $\beta 2$-laminin chain was isolated from the human esophagus with the ability to reconstitute the esophageal epithelium in vitro (Seery and Watt, 2000). It has also shown that bone marrow stem cells may contribute to cell regeneration of normal and injured rat esophagus (Sarosi et al., 2008).

\subsection{Stem cell markers involved in cancer development and evolution}

It is a matter of crucial importance to known the markers characteristics of stem cells whose expression is significantly increased in the esophageal cancer cells and that would be involved in cancer development and associated with a poorer clinical outcome. However, there is little information about the phenotype and the biology of the stem cells and the cancer stem cells responsible of the low five-year survival rate in esophageal cancer (Kalabis et al., 2008; Nguyen et al., 2011).

The CD44, a glycoprotein involved in cell motility and migration, is one of the most used markers for the identification of CSCs in multiple tissues (Nguyen et al., 2011; Quante and Wang, 2009). CD44 is also a marker of esophageal CSCs and its expression is associated with metastasis and a poor prognosis (Takayama et al., 2003). However, CD133, another common CSC marker was not expressed in EA stem cells (Grotenhuis et al., 2010).

SP cells in the esophagus presented CSCs characteristics indicated by higher clone formation efficiency, up-regulation of stem-cell related genes such as Oct- 4 and Sox-2, up-regulation of the $\mathrm{ABC}$ transporter genes, increased expression of the Notch and Wnt-related genes and a higher expression of beta-catenin protein (Epperly et al., 2004; Huang et al., 2009).

Analysis of tumors obtained from ESCC patients demonstrated a high expression of Oct-4 and Sox-2 genes and this expression was significantly associated with a higher histological grade and poorer clinical outcome (Bass et al., 2009; Wang et al., 2009; X. Zhou et al., 2011). The HIWI gene was identified in hematopoietic stem cells and germ cells and plays a role in 
stem cell pluripotency, self-renewal and differentiation. HIWI was also detected in human ESCC and its over-expression was associated with higher histological grade and poorer overall survival (He et al., 2009).

Musashi-1 is a RNA-biding protein identified as a marker of the intestinal stem cells and found in BE and significantly increased in EA, whereas it is absent in normal squamous epithelium indicating an important role in the development and maintenance of the esophagus diseases or even the cell of origin for esophagus cancer (Bobryshev et al., 2010).

Leucine-rich-repeat-containing G-protein-coupled receptor (LgR5) was first proposed as an intestinal stem cell marker and recently identified in EA but not in ESCC patients. LgR5 expression is related with the low survival rate in these patients (von Rahden et al., 2011). The neural stem cell marker low-affinity neurotrophin receptor p75NTR is expressed in esophageal keratinocyte stem cells with high proliferation properties (Okumura et al., 2003). This marker was present in an elevated number of ESCC and EA patients (Okumura et al., 2006; Sun et al., 2009). p75NTR could be a potential target for future specific esophageal therapies.

\subsection{Adult stem cells as an approach for the treatment of gastrointestinal diseases}

In recent years, the progress in stem cells identification and characterization indicate the potential therapeutic applications of stem cells in regenerative medicine for the treatment of several pathologies. The different types of stem cells, embryonic, induced pluripotent and adult stem cells are emerging as a potential approach to treat gastrointestinal disorders. Stem cells could be classified in two main groups, i.e., embryonic and adult stem cells. There is an increasing interest in the potential use of stem cells in regenerative medicine.

\subsubsection{Embryonic stem cells}

Embryonic stem cells (ESCs) have a high proliferation and differentiation capacity (pluripotency). However, there are several limitations to their use for therapeutic purposes including the ethical considerations, the elevated self-renewal properties that will induce tumors and the immune rejection as they are not patient-derived (Ao et al., 2011).

The induced pluripotent stem cells (iPSCs) are stem cells obtained from somatic stem cells by transfer of exogenous genes involved in the maintenance of ECSs. The iPSCs can be generated from the patients' somatic cells preventing the immune rejection. However, like ESCs the risk of teratoma formation is an important problem to be overcome for future clinical application (Kooreman and $\mathrm{Wu}, 2010)$.

\subsubsection{Adult stem cells}

Adult stem cells are undifferentiated cells present a tissue or organ in very small amounts that can renew by themselves and differentiate into all of the specialized cell types of the tissue or organ. The principal role of adult stem cells is to maintain and repair the tissue in which they are found in case of any disease or injury. Adult stem cells have been found in almost all adult tissues, even in more tissues than was thought possible. Several adult stem cells such as adult hematopoietic stem cells from bone marrow or from umbilical cord blood have been used in transplants for 40 or 20 years, respectively. 
Mesenchymal stem cells (MSCs) are adult stem cells also present in bone marrow. These non-hematopoietic stem cells are isolated from bone marrow by their adherence to the plastic plates after culture and characterized by the expression of a set of markers (CD105, CD73 and CD90) and the lack of expression of hematopoietic markers (CD45, CD34, CD14 or CD11b, CD79a or CD19) and the HLA class II surface molecules (Dominici et al., 2006). MSC are multipotent cells with the capacity of differentiation into bone, fat and cartilage (Horwitz et al., 2005). In addition to the mesodermal differentiation, MSC have been differentiated to cells of the endodermal and ectodermal embryonic layers. This differentiation capacity as well as their immunosuppressive and immunomodulatory properties makes MSCs a very attractive resource for tissue regeneration (Liu et al., 2009). Bone marrow MSC are the most used cells in both experimental and clinical settings, although MSCs have been isolated from numerous sources such as adipose tissue, umbilical cord blood, umbilical cord tissue, amniotic fluid and placenta (Broxmeyer et al., 2006; De Coppi et al., 2007; Igura et al., 2004; Macias et al., 2010; Miki et al., 2005; Sarugaser et al., 2005; Soncini et al., 2007; Tallone et al., 2011).

Human placenta is an especially complex organ composed of both fetal and maternal tissues. At the time of birth, placenta loses its function and is normally discarded. MSC obtained from human placenta are stem cells without ethical concerns, isolated without invasive procedures and present low risk of viral infection (Hemberger et al., 2008; Pappa and Anagnou, 2009; Parolini et al., 2008). Recently, we have described the isolation and characterization of a population of MSCs from the maternal part of human placenta, i.e. decidua parietalis (Macias et al., 2010). The cells named Decidua-derived Mesenchymal Stem Cells (DMSC) is a homogeneous population of MSCs that showed high proliferation and differentiation capacity into cell types from the three embryonic layers, genomic stability and until senescence and a decrease in telomerase activity indicating that DMSCs could be safely used in regenerative medicine. In addition, DMSCs are hypo-immunogenic cells suggesting that they could be used in both, autologous and allogenic transplantation for future clinical trials.

\subsubsection{Mesenchymal stem cells for the treatment of gastrointestinal diseases}

Recent studies have revealed that MSCs selectively migrate and home in on to damaged tissues and organs after systemic or local application (Kidd et al., 2009). This tropism for sites of injury, irrespective of the tissue or organ, indicates that MSCs can be useful as cellular vehicles as tumors are considered as "wounds that never heal" (Dvorak, 1986). Indeed, bone marrow stem cells migrate to esophageal epithelium and contribute to tissue regeneration under normal and/or pathological conditions (Sarosi et al., 2008). These migratory properties make MSCs a useful and efficient tool for the delivery of therapeutic anti-tumor genes to the tumor area (Hall et al., 2007). MSCs will later produce and release the anticancer agents in situ which would significantly increase the efficacy and decrease the side effects of these therapeutic agents (Nakamizo et al., 2005; Studeny et al., 2002; Studeny et al., 2004). Besides, these authors showed also evidences that MSCs can also be used as therapeutic agents themselves. The use of MSCs as cellular delivery vehicles offer several advantages such as MSCs from several sources are easy to isolate and culture; can be expanded in culture without losing their characteristics; and are hypoimmunogenic and 
show immunomodulatory properties to be well tolerated in allogeneic transplantation (Horwitz et al., 2005; Macias et al., 2010).

\section{Conclusion}

In EA and ESCC patients, standard treatments are similar although it is necessary to develop earlier diagnosis because of the poor prognosis of esophageal cancer compared to other digestive cancers. It is necessary to select the most appropriate predictive biomarkers especially, those assayed in esophageal tissue- and determined in with the aim of designing specific treatments for each type of esophagus cancer patients and obtain a clear clinical benefit. The overall expression of a set of single markers together with the clinical data would be useful to predict the development and evolution of this type of tumors.

In the near future, integrated approaches to biomarkers discovery and development, analyses and simulations to predict and identify the most specific biomarkers in esophagus cancer, are necessary. In addition, will be important bioinformatics analyses and tissue array studies (genomic, proteomic and transcriptomic-based biomarkers) with high quality clinical samples.

The molecular and cellular events responsible for regulating both, the replacement of the normal esophageal epithelium and the development and maintenance of cancer are not well understood. It is important to understand how the stem cells fate is regulated and the factors that play a role in its de-regulation and will contribute to the formation of a tumor. MSCs contribute to the regeneration of several tissues and could be used as cellular vehicles of anti-cancer drugs increasing their efficacy and decreasing the side effects which would greatly improve the quality of life of esophagus cancer patients. In summary, understanding the biology of normal esophageal epithelium and the role of the biomarkers of tumor, nontumor and esophageal stem cells it is crucial for designing more specific therapies in order to increase the reduced current clinical outcomes of esophagus cancer patients.

\section{References}

Adams, J.M. \& Strasser, A. (2008). Is tumor growth sustained by rare cancer stem cells or dominant clones? Cancer Research, Vol. 68, No. 11, (June 2008), pp. 4018-4021, ISSN 0008-5472, EISSN 1538-7445

Aloia, T.A.; Harpole, D.H. Jr.; Reed, C.E.; Allegra, C.; Moore, M.B.; Herndon, J.E. 2nd \& D'Amico, T.A. (2001). Tumor marker expression is predictive of survival in patients with esophageal cancer. Annual Thoracic Surgery, Vol. 72, No. 3, (September 2001), pp. 859-866, ISSN 0003-4975, EISSN 1552-6259

Anderson, G.M.; Nakada, M.T. \& DeWitte, M. (2004). Tumor necrosis factor- $\alpha$ in the pathogenesis and treatment of cancer. Current Opinion in Pharmacology, Vol. 4, No. 4 (August 2004), pp.314-320, ISSN 1471-4892, EISSN 1471-4973

Ao, A.; Hao J. \& Hong, C.C. (2011). Regenerative chemical biology: current challenges and future potential. Chemistry E Biology, Vol.18, No. 4 (April 2011) pp. 413-424, ISSN $1472-6769$

Bass, A.J.; Watanabe, H.; Mermel, C.H.; Yu, S.; Perner, S.; Verhaak, R.G.; Kim, S.Y.; Wardwell, L.; Tamayo, P.; Gat-Viks, I.; Ramos, A.H.; Woo, M.S.; Weir, B.A.; Getz, 
G.; Beroukhim, R.; O'Kelly, M.; Dutt, A.; Rozenblatt-Rosen O.; Dziunycz, P.; Komisarof, J.; Chirieac, L.R.; LaFargue, C.J.; Scheble, V.; Wilbertz, T.; Ma, C.; Rao, S.; Nakagawa, H.; Stairs, D.B.; Lin, L.; Giordano, T.J.; Wagner, P.; Minna, J.D.; Gazdar, A.F.; Zhu, C.Q.; Brose, M.S.; Cecconello, I.; Ribeiro U. Jr.; Marie, S.K.; Dahl, O.; Shivdasani, R.A.; Tsao, M.S.; Rubin, M.A.; Wong, K.K.; Regev, A.; Hahn, W.C.; Beer, D.G.; Rustgi, A.K. \& Meyerson, M.. (2009). SOX2 is an amplified lineagesurvival oncogene in lung and esophageal squamous cell carcinomas. Nature Genetics, Vol. 41, No.11, (November 2009), pp.1238-1242, ISSN 1061-4036, EISSN 1546-1718

Bauer, E.A.; Strick, G.P.; Jeffry, J.J. \& Eisen, A.Z. (1975). Collagenase production by human skin. Biochemical and Biophysical Research Communications Vol. 64, No. 1, (May 1975), pp. 232-240, ISSN 0006-291X

Bearz, A.; Talamini, R.; Vaccher, E.; Spina, M.; Simonelli, C.; Steffan, A.; Berretta, M.; Chimienti, E. \& Tirelli, U. (2007). MUC-1 (CA 15-3 antigen) as a highly reliable predictor of response to EGFR inhibitors in patients with bronchioloalveolar carcinoma: an experience on 26 patients. The International Journal of Biological Markers Vol. 22, No. 4, (Oct-Dec), pp. 307-311, ISSN 1724-6008, EISSN 1724-6008

Bedoya, F.; Meneu, J.; Macias, M.I.; Moreno, A.; Enríquez de Salamanca, R.; MorenoGonzalez, E. \& Vegh, I. (2009a). Mutation in CNR1 gene and VEGF expression in esophageal cancer. Tumori, Vol.95, No. 1, (January-February 2009), pp.68-75; ISSN 0300-8916, EISSN 2038-2529

Bedoya, F.; Rubio, J.C.; Morales-Gutierrez, C.; Abad-Badahona, A.; Lora Pablos, D.; Meneu, J.C.; Moreno-Gonzalez, E.; Enriquez de Salamanca, R. \& Vegh, I. (2009b) Single nucleotide change in the cannabinoid receptor-1 (CNR1) gene in colorectal cancer outcome. Oncology (Basel), Vol. 76, No. 6, (May 5), pp. 435-441; ISSN 0030-2414, EISSN 1423-0232

Bellet, D.H.; Wands, J.R.; Isselbacher, K.J. \& Bohuon, C. (1984). Serum alpha fetoprotein levels in human disease: perspective from a highly specific monoclonal radioimmunoassay. Proceedings of the National Academy of Sciences USA Vol. 81, No. 12, (June 1984), pp. 3869-3873; ISSN 0027-8424, EISSN 1091-6490

Bendardaf, R.; Bumeida, A.; Hilska, M.; Laato, M.; Syrjänen, K.; Collan, Y. \& Pyrhönen, S. (2008) VEGF-1 expression in colorectal cancer is associated with disease localization, stage, and log-term disease specific survival. Anticancer Research, Vol. 28, No. 6B, (November-December 2008), pp. 3865-3870, ISSN0250-7005, EISSN 17917530

Blant, S.A.; Ballini, J.P.; Caron, C.T.; Fontolliet, C.; Monnier, P. \& Laurini, N.R. (2001). Evolution of DNA ploidy during squamous cell carcinogenesis in the esophagus. Diseases of Esophagus, Vol. 14, No. 3-4 (October 2001), 178-184, ISSN 1120-8694, EISSN 1442-2050

Bobryshev, Y.V., Freeman A.K., Botelho N.K., Tran D., Levert-Mignon A.J. \& Lord R.V.(2010). Expression of the putative stem cell marker Musashi-1 in Barrett's esophagus and esophageal adenocarcinoma. Diseases of Esophagus, Vol. 23, No. 7, (September 2010), pp. 580-58, ISSN 1120-8694, EISSN 1442-2050 
Bosman, F.T. \& Stamenkovic, I. (2003) Funtional structure and composition of the extracellular matrix. Journal of Pathology, Vol. 200, No. 4, (July 2003), pp. 423-428, ISSN 0022-3417, EISSN 1600-0714

Brooks, P.C.; Silletti, S.; von Schalscha, T.L.; Friedlander, M. \& Cheresh, D.A. (1998). Disruption of angiogenesis by PEX, a noncatalytic metalloproteinase fragment with integrin binding activity. Cell, Vol. 92, No.3, (February 1998), pp. 391-400, ISSN 0092-8674, EISSN 1097-4172

Broxmeyer, H.E.; Srour, E.; Orschell, C.; Ingram, D.A.; Cooper, S.; Plett, P.A.; Mead, L.E. \& Yoder, M.C. (2006). Cord blood stem and progenitor cells, In: Methods in Enzymology, Edited by Irina Klimanskaya and Robert Lanza, Vol. 419, pp.439-473, Elsevier, ISBN 978-0-12-373650-5

Burg-Kurland, C.L.; Purmell, D.M.; Combs, J.W.; Hillman, E.A.; Harris, C.C. \& Trump, B.F. (1989). Immunocytochemical evaluation of human esophageal neoplasms and preneoplastic lesions for beta-chorionic gonadotropin, placental lactogen, alphafetoprotein, carcinoembryonic antigen, and nonspecific cross-reacting antigen. Cancer Research, Vol. 46, No. 11 (November 1986), pp. 2936-2943, ISSN 0008-5472, EISSN 1538-7445

Clemons, N.J.; Shannon, N.B.; Abeyratne, L.R.; Walker, C.E.; Saadi, A.; O’Donovan, M.L.; Lao-Sirieix, P.P. \& Fitzgerald, R.C. (2010). Nitric oxide-mediated invasion in Barrett's high-grade dysplasia and adenocarcinoma. Carcinogenesis, Vol. 31, No. 9, (September 2010), pp. 1669-1675, ISSN 0143-3334, EISSN 1460-2180

Croagh, D., Phillips, W.A.; Redvers, R.; Thomas, R.J. \& Kaur, P. (2007). Identification of candidate murine esophageal stem cells using a combination of cell kinetic studies and cell surface markers. Stem Cells, Vol. 25, No. 2, (February 2007), pp. 313-318, EISSN 1549-4918

Croagh, D.; Thomas, R.J.; Phillips, W.A. \& Kaur, P. (2008). Esophageal stem cells-a review of their identification and characterization. Stem Cell Reviews, Vol. 4, No. 4, (December 2008), pp. 261-268, ISSN 1550-8943

Dai, S.; Mao, C.; Jiang, L.; Wang, G. \& Cheng H. (2009). P53 polymorphism and lung cancer susceptibility: a pooled analysis of 32 case-control studies. Human Genetics, Vol. 125, No, 5-6, (June 2009), pp. 633-638, ISSN 0340-6717, EISSN 1432-1203

D'Amico, T.A. \& Harpole, D.H. Jr. (2000). Molecular biology of esophageal cancer. Chest surgery clinics of North America, Vol. 10, No. 3, (August 2000), pp. 451-469, ISSN 1052-3359

De Coppi, P.; Bartsch, G. Jr.; Siddiqui, M.M.; Xu, T.; Santos, C.C.; Perin, L.; Mostoslavsky, G.; Serre, A.C.; Snyder, E.Y.; Yoo, J.J.; Furth, M.E.; Soker, S. \& Atala, A. (2007). Isolation of amniotic stem cell lines with potential for therapy. Nature Biotechnology, Vol. 25, No.1, (January 2007), pp. 100-106, ISSN1087-0156, EISSN 1546-1696

Dominici, M.; Le Blanc, K.; Mueller, I.; Slaper-Cortenbach, I.; Marini, F.; Krause, D.; Deans, R.; Keating, A.; Prockop, D. \& Horwitz, E. (2006). Minimal criteria for defining multipotent mesenchymal stromal cells. The International Society for Cellular Therapy position statement. Cytotherapy, Vol. 8, No. 4, (August 2006), pp. 315-317, ISSN 1465-3249, EISSN 1477-2566 
Dumont, P.; Leu, J.I.; Della Pietra, A.C. 3rd; George, D.L. \& Murphy, M. (2003) The codon 72 polymorphic variants of p53 have markedly different apoptotic potential. Nature Genetics, Vol. 33, No. 3, (March 2003), pp. 357-365, ISSN 1061-4036, EISSN1546-1718

Dvorak, H.F. (1986). Tumors: wounds that do not heal. Similarities between tumor stroma generation and wound healing. New England Journal of Medicine, Vol. 315, No.26 (December 1986), pp.1650-1659, ISSN 0028-4793, EISSN1533-4406

Eng, C.; Spechler, S. J.; Ruben, R. \& Li, F.P. (1993). Familial Barrett esophagus and adenocarcinoma of the gastroesophageal junction. Cancer Epidemiology Biomarkers $\mathcal{E}$ Prevention, Vol. 2, No. 4, (July-August 1993), pp. 397-399, ISSN 1055-9965, EISSN1538-7755

Epperly, M.W.; Shen, H.; Jefferson, M. \& Greenberger, J.S. (2004). In vitro differentiation capacity of esophageal progenitor cells with capacity for homing and repopulation of the ionizing irradiation-damaged esophagus. In Vivo, Vol.18 No. 6, (NovemberDecember 2004), pp. 675-85, ISSN 0258-851X

Etoh, T.; Inoue, H.; Yoshikawa, Y.; Barnard, G.F.; Kitano, S. \& Mori, M. (2000). Increased expression of collagenase-3 (MMP-13) and MT1-MMP in esophageal cancer is related to cancer aggressiveness. Gut, Vol. 47, No. 1, (July 2000), pp. 50-56, ISSN 0017-5749, EISSN 1468-3288

Fang, M.; Lew, E.; Klein, M.; Sebo, T.; Su, Y. \& Goyal, R. (2004). DNA abnormalities as marker of risk for progression of Barrett's esophagus to adenocarcinoma: image cytometric DNA analysis in formalin-fixed tissues. The American Journal of Gastroenterology, Vol. 99, No. 10, (October 2004), pp. 1887-1894, ISSN 0002-9270, EISSN1572-0241

Ferrara, N. \& Davis-Smyth, T. (1997). The biology of vascular endothelial growth factor. Endocrine Reviews, Vol. 18, No. 1, (February 1997), pp. 4-15, ISSN 0163-769X, EISSN1945-7189

Folkman, J. (1990). What is the evidence that tumours are angiogenesis dependent? Journal of the National Cancer Institute, Vol. 82, No. 1, ( January 3, 1990), pp. 68-75, ISSN 00278874, EISSN1460-2105

Frederick, P.J.; Ramirez, P.T.; McQuinn, L.; Milam, M.R.; Weber, D.M.; Coleman, R.L.; Gershenson, D.M. \& Landen, C.N. Jr. (2011). Preoperative factors predicting survival after secondary cytoreduction for recurrent ovarian cancer. International Journal of Gynecological Cancer, Vol. 21, No.5, (July 2011), pp. 831-836, EISSN 15251438

Fujiwara, Y.; Higuchi, K.; Hamaguchi, M.; Takashima, T.; Watanabe, T.; Tominaga, K.; Oshitani, N.; Matsumoto, T.\& Arakawa, T. (2004). Increased expression of transforming growth factor-alpha and epidermal growth factor receptors in rat chronic reflux esophagitis. Journal of Gastroenterology and Hepatology, Vol. 19, No. 5, (May 2004), pp.521-527, ISSN 0815-9319, EISSN1440-1746

Gadzicki, D.; Müller-Vahl, K. \& Stuhrmann, M. (1999). A Frequent polymorphism in the coding exon of the human cannabinoid receptor (CNR1) gen. Molecular and Cellular Probes, Vol. 13, No. 4, (August 1999), pp. 321-323, ISSN 0890-8508, EISSN1096-1194 
Gillis, S.; Ferm, M.; Ou, W. \& Smith, K.A. (1978). T cell growth factor: parameters of production and a quantitative microassay for activity. The Journal of Immunology, Vol. 120, No. 6, (June 1978), pp. 2017-2032, ISSN 0022-1767, EISSN1550-6606

Gold, P. \& Freedman, S.D. (1965). Demonstration of tumor-specific antigens in human colonic carcinomata by immunological tolerance and absortion techniques. The Journal of Experimental Medicine, Vol. 121, No. 3, (March 1965), pp. 439-462, ISSN 0022-1007, EISSN1540-9538

Gomez, D.E.; Alonso, D.F.; Yoshiji, H. \& Thorgeirsson, U.P. (1997). Tissue inhibitors of metalloproteinases: structure, regulation and biological function. The European Journal of Cell Biology, Vol. 74, No. 2 (October 1997), pp. 111-122, ISSN 0171-9335

Grimm, M.; Lazariotou M.; Kircher, S.; Stuermer, L.; Reiber, C.; Höfelmayr, A.; Gattenlöhner, S.; Otto, C.; Germer, C.T. \& von Rahden, B.H.A. (2010). MMP-1 is a pre-invasive factor in Barrett- associated esophageal adenocarcinomas and is associated with positive lymph node status. Journal of Translational Medicine, Vol. 8, (October 2010), pp. 99, ISSN 1479-5876

Grotenhuis, B.A.; Dinjens, W.N.; Wijnhoven, B.P; Sonneveld, P.; Sacchetti, A.; Franken, P.F.; van Dekken, H.; Tilanus, H.W.; van Lanschot, J.J. \& Fodde, R.(2010). Barrett's oesophageal adenocarcinoma encompasses tumour-initiating cells that do not express common cancer stem cell markers. The Journal of Pathology, Vol. 221, No. 4, (August 2010), pp. 379-389, ISSN 0022-3417, EISSN 1096-9896

Hall, B.; Dembinski, J.; Sasser, A.K.; Studeny, M.; Andreeff, M. \& Marini, F. (2007). Mesenchymal stem cells in cancer: tumor-associated fibroblasts and cell-based delivery vehicles. International Journal of Hematology, Vol. 86, No. 1, (July 2007), pp. 8-16, ISSN 0925-5710, EISSN1865-3774

He, W.; Wang, Z.; Wang, Q.; Fan, Q.; Shou, C.; Wang, J.; Giercksky, K.E.; Nesland, J.M. \& Suo, Z. (2009). Expression of HIWI in human esophageal squamous cell carcinoma is significantly associated with poorer prognosis. BMC Cancer, Vol. 9, No. (December 2009), pp. 426-436, ISSN 1471-2407

Hemberger, M.; Yang, W.; Natale, D.; Brown, T.L.; Dunk, C.; Gargett, C.E. \& Tanaka, S. (2008). Stem cells from fetal membranes - a workshop report. Placenta, Vol. 29, Suppl. A, (March 2008), pp. S17-19, ISSN 0143-4004

Hormi-Carver, K. \& Souza, R.F. (2009). Molecular markers and genetics in cancer development. Surgical oncology clinics of North America, Vol. 18, No. 3, (July 2009), pp. 453-467, ISSN 1055-3207, EISSN 1558-5042

Horwitz, E.M.; Le Blanc, K.; Dominici, M. I.; Mueller, I.; Slaper-Cortenbach, F.; Marini, C.; Deans, R.J.; Krause, D.S. \& Keating, A. (2005). Clarification of the nomenclature for MSC: The International Society for Cellular Therapy position statement. Cytotherapy, Vol. 7, No. 5, (January 2005), pp. 393-395, ISSN 1465-3249, EISSN14772566

Hrstka, R.; Coates, P.J. \& Vojtesek, B. (2009) Polymorphisms in p53 and the p53 pathway: roles in cancer susceptibility and response to treatment. Journal of Cellular and Molecular Medicine, Vol. 13, No. 3, (March 2009), pp. 440-453 ISSN 1582-1838, EISSN 1582-4934 
Huang, D.; Gao, Q.; Guo, L.; Zhang, C.; Jiang, W.; Li, H.; Wang, J.; Han, X.; Shi, Y. \& Lu, S.H. (2009). Isolation and identification of cancer stem-like cells in esophageal carcinoma cell lines. Stem Cells and Development, Vol. 18, No. 3, (April 2009), pp. 465-473, ISSN 1547-3287, EISSN 1557-8534

Igura, K.; Zhang, X.; Takahashi, K.; Mitsuru, A.; Yamaguchi, S. \& Takashi, T.A. (2004). Isolation and characterization of mesenchymal progenitor cells from chorionic villi of human placenta. Cytotherapy, Vol. 6, No. 6, (January 2004), pp. 543-53, ISSN 14653249, EISSN1477-2566

Inada, S.; Koto, T.; Futami, K.; Arima, S. \& Iwashita, A. (1999) Evaluation of malignancy and prognosis of esophageal cancer based on an immunohistochemical growth factor receptor. Surgery Today, Vol. 29 No. 6, (June 1999), pp. 493-503, ISSN 0941-1291, EISSN 1436-2813

Inoue, K.; Ozeki, Y.; Suganuma, Y.; Sugiura, Y. \& Tanaka, S. (1997). Vascular endotelial growth factor expression in primary oesophageal squamous cell carcinoma: association with angiogenesis and tumor progression. Cancer, Vol. 79, No. 2, (January 1997), pp. 206-213. ISSN 0008-543X, EISSN1097-0142

Jiang, D.K.; Yao, L.; Wang, W.Z.; Peng, B.; Ren, W.H.; Yang, X.M. \& Yu, L. (2010) TP53 Arg72Pro polymorphism and esophageal cancer. World Journal of Gastroenterology, Vol. 17, No. 9, (March 2010) pp. 1227-1233, ISSN 1007-9327

Kalabis, J.; Oyama, K.; Okawa, T.; Nakagawa, H.; Michaylira, C.Z.; Stairs, D.B.; Figueiredo, J.L.; Mahmood, U.; Diehl, J.A.; Herlyn, M. \& Rustgi, A.K. (2008). A subpopulation of mouse esophageal basal cells has properties of stem cells with the capacity for self-renewal and lineage specification. The Journal of Clinical Investigation, Vol. 118, No. 12 (December 2008), pp. 3860-3869, ISSN 0036-5513, EISSN 1502-7686

Kidd, S.; Spaeth, E.; Dembinski, J.L.; Dietrich, M.; Watson, K.; Klopp, A.; Battula, V.L.; Weil, M.; Andreeff, M. \& Marini, F.C. (2009). Direct evidence of mesenchymal stem cell tropism for tumor and wounding microenvironments using in vivo bioluminescent imaging. Stem Cells, Vol. 27, No. 10, (October 2009), pp. 2614-2623, EISSN 1549-4918

Kijima, H.; Oshiba, G.; Kenmochi, T.; Kise, Y.; Tanaka, H.; Chino, O.; Shimada, H.; Ueyama, Y. \& Makuuchi, H. (2000). Stromal CEA activity is correlated with lymphatic invasion of esophageal carcinoma. The International Journal of Oncology, Vol. 16, No. 4, (April 2000), pp. 677-682, ISSN 1341-9625, EISSN1437-7772

Kilic, A.; Owens, S.R.; Pennathur, A.; Luketich, J.D.; Landreneau, R.J. \& Schuchert, M.J. (2009). An increased proportion of inflammatory cells express tumor necrosis factor alpha in idiopathic achalasia of the esophagus. Diseases of Esophagus, Vol. 22, No. 5, (August 2009), pp. 382-385, ISSN 1120-8694, EISSN1442-2050

Kim, Y.H.; Ajani, J.A.; Ota, D.M.; Lynch, P. \& Roth, J.A. (1995) Value of serial carcinoembryonic antigen levels in patients with resectable adenocarcinoma of esophagus and stomach. Cancer, Vol. 75, No. 2, (January 1995), pp. 451-456, ISSN 0008-543X, EISSN1097-0142

Kimura, S.; Kitadai, Y.; Tanaka, S.; Kuwai, T.; Hihara, J.; Yoshida, K.; Toge, T. \& Chayama, K. (2004) Expression of hypoxia-inducible factor (HIF)-1a expression and tumour angiogenesis in human oesophageal squamous cell carcinoma. The European Journal 
of Cancer, Vol. 40, No. 12, (August 2004), pp. 1904-1912, ISSN 0959-8049, EISSN18790852

Kooreman, N.G. \& Wu, J.C. (2010). Tumorigenicity of pluripotent stem cells: biological insights from molecular imaging. Journal of the Royal Society Interface, Vol. 7, Suppl. 6, (December 2010), pp. S753-763, ISSN 1742-5689, EISSN 1742-5662

Kosugi, S.; Nishimaki, T.; Kanda, T.; Nagawa, S.; Ohashi, M. \& Hatakeyama, K. (2004) Clinical significance of serum CEA, carbohydrate antigen 19-9, and squamous cell carcinoma levels in esophageal cancer patients. World Journal of Surgery, Vol. 28, No. 7, (July 2004), pp. 680-685, ISSN0364-2313, EISSN1432-2323

Kuwano, H.; Kato, H.; Miyazaki, T.; Fukuchi, M.; Masuda, N.; Nakajima, M.; Fukai, Y.; Sohda, M.; Kimura, H. \& Faried, A. (2005). Genetic alterations in esophageal cancer. Surgery Today, Vol. 35, No. 1 (January 2005), pp. 7-18, ISSN0941-1291, EISSN 1436-2813

Lao-Sirieix, P.; Lovat, L. \& Fitzgerald, R.C. (2007). Cyclin A immunocytology as a risk stratification tool for Barrett's esophagus: association with increased risk of adenocarcinoma. Clinical Cancer Research, Vol. 13, No. 2 Pt 1, (January 2007), pp. 659-665, ISSN 0008-5472, EISSN1538-7445

Lehrbach, D.M.; Cecconello, I.; Ribeiro, Jr. U.; Capelozzi, V.L.; Ab'saber, A.M. \& Alves, V.A. (2009). Adenocarcinoma of the esophagastric junction: relationship between clinicopathological data and p53, cyclin D1 and Bcl-2 immunoexpressions. Arquivos de Gastroenterologia, Vol. 46, No. 4, (October-December 2009), pp. 315-320, ISSN 0004-2803, EISSN1678-4219

Levine, A.J.; Momand, J. \& Finlay, C.A. (1991). The p53 tumor suppressor gene. Nature, Vol. 351, No. 6326, (June 1991), pp. 453-456, ISSN 0028-0836, EISSN1476-4687

Levine, A.J.; Finlay, C.A. \& Hinds, P.W. (2004) P53 is a tumor suppressor gene. Cell, Vol. 116, No. 2 Supplement, (January 2004), pp. S67-S69, ISSN 0092-8674, EISSN1097-4172

Li, Z.; Shimada, Y.; Uchida, S.; Maeda, M.; Kawabw, A.; Mori, A.; Kano, M.; Watanabe, G \& Immamura, M. (2000). TGF-alpha as well as VEGF, PD-ECGF and b FGF contribute to angiogenesis of esophageal squamous carcinoma. The International Journal of Oncology, Vol. 17, No. 3, (September 2000), pp. 453-460, ISSN 1341-9625, EISSN14377772

Liu, Z.J.; Zhuge, Y. \& Velazquez, O.C. (2009). Trafficking and differentiation of mesenchymal stem cells. Journal of Cellular Biochemistry, Vol. 106, No. 6, (April 2009), pp. 984-991, ISSN 0730-2312, EISSN 1097-4644

Liu, X.; Cheng, Y.; Sheng, W.; Lu, H.; Xu, Y.; Long, Z.; Zhu, H. \& Wang, Y. (2010). Clinicopathologic features and prognostic factors in alpha-fetoprotein-producing gastric cancers: analysis of 104 cases. Journal of Surgical Oncology, Vol. 102, No. 3, (September 2010), pp. 249-255, ISSN 0022-4790, EISSN1096-9098

Liu M, Wang Z, Yang S, Zhang W, He S, Hu C, Zhu H, Quan L, Bai J, Xu N. (2011). TNF-a is a novel target of miR-19a. The International Journal of Oncology, Vol. 38, No. 4, (April 2011), pp. 1013-1022, ISSN 1341-9625, EISSN1437-7772

Lord, R.V.; O'Grady, R.; Sheehan, C.; Field, A.F. \& Ward, R.L. (2000). K-ras codon 12 mutations in Barrett's oesophagus and adenocarcinomas of the oesophagus and 
oesophagogastric junction. Journal of Gastroenterology and Hepatology, Vol. 15, No. 7, (July 2000), pp. 730-736, ISSN 0815-9319, EISSN1440-1746

Lynch, T.J.; Bell, D.W.; Sordella, R.; Gurubhagavatula, S. \& Okimoto, R.A. (2004) Activating mutations in the epidermal growth factor receptor underlying responsiveness of non-small-cell lung cancer of gefitinib. The New England Journal of Medicine, Vol. 350, No. 21, (May 2004), pp. 2129-2139, ISSN 0028-4793, EISSN1533-4406

Macias, M.I.; Grande, J.; Moreno, A.; Dominguez, I.; Bornstein, R. \& Flores, A.I. (2010). Isolation and characterization of true mesenchymal stem cells derived from human term decidua capable of multilineage differentiation into all 3 embryonic layers. American Journal of Obstetrics and Gynecology, Vol. 203, No.5, (November 2010), pp. 495.e9-495.e23, ISSN 0002-9378, EISSN1097-6868

McKnight, A.; Marnell, A. \& Shperling, J. (1989). The role of carbohydrate antigen 19-9 as a tumour marker of oesophagus cancer, British Journal of Cancer, Vol. 60, No. 2, (August 1989), pp. 249-251, ISSN 0007-0920, EISSN1532-1827

Matlashewski, G.J.; Tuck, S.; Pim, D.; Lamb, P.; Schneider, J. \& Crawford, L.V. (1987). Primary structure polymorphism at amino acid residue 72 of human p53. Molecular and Cell Biology, Vol. 7, No. 2, (February 1987), pp. 961-963, ISSN 0270-7306, EISSN1098-5549

Maurel, J.; Nadal, C.; Garcia-Albeniz, X.; Gallego, R.; Carcereny, E.; Almendro, V.; Mármol, M.; Gallardo, E.; Maria Augé, J.; Longarón, R.; Martínez-Fernandez, A.; Molina, R., Castells, A. \& Gascón, P. (2007). Serum matrix metalloproteinase 7 levels identifies poor prognosis advanced colorectal cancer patients. International Journal of Cancer, Vol. 121, No. 5, (September 2007), pp. 1066-1071, ISSN 0020-7136, EISSN 1097-0215

Miki, T.; Lehmann, T.; Cai, H.; Stolz, D.B. \& Strom, S.C. (2005). Stem cell characteristics of amniotic epithelial cells. Stem Cells, Vol. 23, No. 10, (November-December 2005), pp. 1549-1559, ISSN 1066-5099, EISSN 1549-4918

Mimori, K.; Mori, M.; Shiraishi, T.; Fujie, T.; Baba, K.; Haraguchi, M.; Abe, R.; Ueo, H. \& Akiyoshi T. (1997). Clinical significance of tissue inhibitor of metalloproteinase expression in gastric carcinoma. The British Journal of Cancer, Vol. 76, No. 4, (August 1997), pp. 531-536, ISSN 0007-0920, EISSN 1532-1827

Minu, A.R.; Endo, M. \& Sunagawa, M. (1994). Role of DNA ploidy patterns in esophageal squamous cell carcinoma. An ultraviolet microspectro-photometric study. Cancer, Vol. 74, No. 2, (July 1994), pp. 578-585, ISSN 0008-543X, EISSN1097-0142

Mizejewski, G.J. (2002). Biological role of alpha-fetoprotein in cancer: prospects for cancer therapy. Expert Review of Anticancer Therapy, Vol. 2, No. 6, (December 2002), pp. 709-735, ISSN 1473-7140

Montesano, R.; Hollstein, M, \& Hainaut, P. (1996) Genetic alterations in esophageal cancer and their relevance to etiology and pathogenesis: a review. International Journal of Cancer, Vol. 69, No. 3, (June 1996), pp. 225-235. ISSN 0020-7136, EISSN1097-0215

Morales-Gutíerrez, C.; Vegh, I.; Colina, F.; Gomez-Cámara, A.; Landa, J.I.; Carreira, P.E. \& Enríquez de Salamanca, R. (1999). Survival of patients with colorectal carcinoma: possible prognostic value of tissular carbohydrate antigen 19.9. Cancer, Vol. 86, No. 9, (November 1999), pp. 1675-1681. ISSN 0008-543X, EISSN 1097-0142 
Mori, R.; Ishiguro, H.; Kimura, M.; Mitsui, A.; Sasaki, H.; Tomoda, K.; Mori, Y.; Ogawa, R.; Katada, T.; Kawano, O.; Harada, K.; Fujii, Y. \& Kuwabara, Y. (2008). PIK3CA mutation status in Japanese esophageal squamous cell carcinoma. Journal of Surgical Reseach, Vol. 145, No. 2, (April 2008), pp. 320-326, ISSN 0022-4804

Motoyama, S.; Miura, M.; Hinai, Y.; Maruyama, K.; Usami, S.; Yoshino, K.; Nakatsu, T.; Saito, H.; Minamuya, Y. \& Ogawa, J.I. (2011). Interleukin-2-330T $>$ G genetic polymorphism associates with prognosis following surgery for thoracic esophageal squamous call cancer. The Annals of Surgical Oncology, Vol. 18, No. 7, (July 2011), pp. 1995-2002, ISSN 1068-9265, EISSN 1534-4681

Murray, G.I.; Duncan, M.E.; O'Neil, P.; McKay, J.A.; Melvin, W.T. \& Fothergill, J.E. (1998). Matrix metalloproteinase-1 is associated with poor prognosis in oesophageal cancer. The Journal of Pathology, Vol. 185, No. 3, (July 1998), pp. 256-61, EISSN 10969896

Nakamizo, A.; Marini, F.; Amano, T.; Khan, A.; Studeny, M.; Gumin, J.; Chen, J.; Hentschel, S.; G. Vecil, J. Dembinski, M. Andreeff, and F.F. Lang. (2005). Human bone marrow-derived mesenchymal stem cells in the treatment of gliomas. Cancer Research, Vol. 65, No. 8, (April 2005), pp. 3307-3318. ISSN 0008-5472, EISSN 15387445

Nguyen, G.H.; Murph, M.M. \& Chang, J.Y. (2011). Cancer Stem Cell Radioresistance and Enrichment: Where Frontline Radiation Therapy May Fail in Lung and Esophageal Cancers. Cancers (Basel), Vol. 3, No. 1, (March 2011), pp. 1232-1252, ISSN 2072-6694

Nordenstedt, H, \& El-Srag, H. (2011). The influence of age, sex and race on the incidence of esophageal cancer in the United States (1992-2006) Scandinavian Journal of Gastroenterology, Vol. 46, No. 5, (May 2011), pp. 597-602, ISSN 0036-5521, EISSN $1502-7708$

Nowell, P.C. (1976). The clonal evolution of tumor cell populations. Science, Vol. 194, No. 4260, (October 1976), pp. 23-28, ISSN 0036-8075, EISSN 1095-9203

Ohashi, S.; Natsuizaka, M.; Wong, G.S.; Michaylira, C.Z.; Grugan, K.D.; Stairs, D,B.; Kalabis, J.; Vega, M.E.; Kalman, R.A.; Nakagawa, M.; Klein-Szanto, A.J., Herlyn, M.; Diehl, A.; Rustgi, A.K. \& Nakagawa, H. (2010). Epidermal growth factor and mutant p53 expand a esophageal subpopulation capable of epithelial-to mesenchymal transition through ZEB transcription factors. Cancer Research, Vol. 70, No. 10, (May 2010), pp. 4174-4184, ISSN 0008-5472, EISSN1538-7445

Okumura, T.; Shimada Y.; Imamura M. \& Yasumoto S. (2003). Neurotrophin receptor p75(NTR) characterizes human esophageal keratinocyte stem cells in vitro. Oncogene, Vol. 22, No. 26, (June 2003), pp. 4017-4026, ISSN 0950-9232, EISSN14765594

Okumura, T.; Tsunoda S.; Mori Y.; Ito T.; Kikuchi K.; Wang T.C.; Yasumoto S.\& Shimada Y. (2006). The biological role of the low-affinity p75 neurotrophin receptor in esophageal squamous cell carcinoma. Clinical Cancer Research, Vol. 12, No. 17, (September 2006), pp. 5096-5103, ISSN 1078-0432, EISSN1557-3265

Oshiba, G; Kijima, J.A.; Ota, D.M.; Lynch, P. \& Roth, J.A. (2000). Frequent expression of sialkyl Lewis (a) in human squamous cell carcinoma. The International Journal of 
Oncology, Vol. 17, No. 4, (October 2000), pp. 701-705, ISSN 1341-9625, EISSN 14377772

Pappa, K.I. \& Anagnou, N.P. (2009). Novel sources of fetal stem cells: where do they fit on the developmental continuum? Regenerative Medicine, Vol. 4, No. 3, (May 2009), pp. 423-433, ISSN 1746-0751, EISSN1746-076X

Parolini, O.; Alviano, F.G.P.; Bagnara, G.; Bilic, H.J.; Buhring, M.; Evangelista, S.; Hennerbichler, B.; Liu, M.; Magatti, N.; Mao, T.; Miki, F.; Marongiu, H.; Nakajima, T.; Nikaido, C.B.; Portmann-Lanz, V.; Sankar, M.; Soncini, G.; Stadler, D.; Surbek, T.A.; Takahashi, H.; Redl, N.; Sakuragawa, S.; Wolbank, S.; Zeisberger, S.; Zisch, A. \& Strom, S.C. (2008). Concise review: isolation and characterization of cells from human term placenta: outcome of the first international Workshop on Placenta Derived Stem Cells. Stem Cells, Vol. 26, No. 2, (February 2008), pp. 300-311, ISSN 1066-5099, EISSN 1549-4918

Pertwee, R.G. (1997). Pharmacology of cannabinoid CB1 and CB2 receptors. Pharmacology $\mathcal{E}$ Therapeutics, Vol. 74, No. 2, pp. 129-180, ISSN 0163-7258

Quante, M. \& Wang, T.C. (2009). Stem cells in gastroenterology and hepatology. Nature Reviews Gastroenterology \& Hepatology, Vol. 6, No. 12, (December 2009), pp. 724-737, ISSN 1759-5045

Rees, J.R.E.; Onwuegbusi, B.A.; Save, V.E.; Alderson, D. \& Fitzgerald R.C. (2006). In vivo and in vitro evidence for transforming growth factor- $\beta 1$-mediated epithelial to masenchymal transition in esophageal adenocarcinoma. Cancer Research, Vol. 66, No. 19, (October 2006), pp. 9583-9590, ISSN 0008-5472, EISSN1538-7445

Romero, Y.; Cameron, A. J.; Locke, G. R.; III, Schaid, D. J.; Slezak, J. M.; Branch, C. D. \& Melton, L.J. (1997). Familial aggregation of gastroesophageal reflux in patients with Barrett's esophagus and esophageal adenocarcinoma. Gastroenterology, Vol. 113, No. 5, (November 1997), pp. 1449-1456, ISSN 0016-5085, EISSN1528-0012

Saadi, A.; Shanon, N.B.; Lao-Sirieix, P.; O’Donovan, M.; Walker, E.; Clemons, N.J.; Hardwick, J.S.; Zhang, C.; Das, M.; Save, V.; Novelli, M.; Balkwill, F. \& Fitzgerald, R.C. (2010). Stromal genes discriminate pre-invasive from invasive disease, predict outcome and highlight inflammatory pathways in digestive cancers. Proceedings of the National Academy of Sciences USA, Vol. 107, No. 5, (February 2010), pp. 21772182, ISSN 0027-8424, EISSN1091-6490

Sanders, D.S.; Wilson, C.A.; Bryant, F.J.; Hopkins, J.; Johnson, G.D.; Milne, D.M. \& Kerr, M.A. (1994). Classification and localization of carcinoembryonic antigen (CEA) related antigen expression in normal esophageal squamous mucosa and squamous carcinoma. Gut, Vol. 35, No. 8, (August 1994), pp. 1022-1025, ISSN 0017-5749, EISSN 1468-3288

Sarosi, G.; Brown, G.; Jaiswal, K.; Feagins, L.A.; Lee, E.; Crook, T.W.; Souza, R.F.; Zou, Y.S.; Shay J.W. \& Spechler, S.J. (2008). Bone marrow progenitor cells contribute to esophageal regeneration and metaplasia in a rat model of Barrett's esophagus. Diseases of Esophagus, Vol. 21, No. 1, (February 2008), pp. 43-50, ISSN 1120-8694, EISSN1442-2050 
Sarosiek, J. \& McCallium, R.W. (2000). Mechanism of oesophageal mucosa defence. Bailliere's Best Practice \& Research Clinical Gastroenterology, Vol. 14, No. 5, (October 2000), pp. 701-717, ISSN 1521-6918

Sarugaser, R.; Lickorish, D.; Baksh, D.; Hosseini, M.M. \& Davies J.E. (2005). Human umbilical cord perivascular (HUCPV) cells: a source of mesenchymal progenitors. Stem Cells, Vol. 23, No. 2, (February 2005), pp. 220-229, ISSN 1066-5099, EISSN 15494918

Seery, J.P. \& Watt, F.M. (2000). Asymmetric stem-cell divisions define the architecture of human oesophageal epithelium. Current Biology, Vol. 10, No. 22, (November 2000), pp. 1447-1450, ISSN 0960-9822, EISSN1879-0445

Shao, L.; Hottelman, W.N.; Lin, J.; Yang, H.; Ajani, J.A. \& Wu, X. (2006). Deficiency of cell cycle checkpoints and ADN repair system predispose individuals to esophageal cancer. Mutation Research, Vol. 602, No. 1-2, (December 2006), pp. 143-150, ISSN 1383-5718

Shimada, H.; Hoshino, T.; Okazumi, S.; Matsubara, H.; Funami, Y.; Nabeya, Y.; Hayashi, H.; Takeda, A.; Shiratori, T.; Uno, T.; Ito, H. \& Ochiai, T. (2002). Expression of angiogenic factors predicts response to chemoradiotherapy and prognosis of oesophageal squamous cell carcinoma. British Journal of Cancer, Vol. 86, No. 4, (February 2002), pp. 552-557, ISSN 0007-0920, EISSN 1532-1827

Shimada, H.; Nabeya, Y.; Okazumi, S.; Matsubara, H.; Shiratori, T.; Gunji, Y.; Kobayashi, H.; Hayashi, H \& Ochiai, T. (2003). Prediction of survival with squamous cell carcinoma antigen in patients with resectable esophageal squamous cell carcinoma. Surgery, Vol. 133, No. 5, (May 2003), pp. 486-494, EISSN 1471-2482

Sobin, L.H. \& Fleming, I.D. TNM Classification of Malignant Tumors, fifth edition (1997). Union Internationale Contre le Cancer and the American Joint Committee on Cancer. Cancer, Vol. 80, No. 9, (November 1997), pp. 1803-1804, ISSN 0008-543X, EISSN 1097-0142

Soncini, M.; Vertua, E.; Gibelli, L.; Zorzi, F.; Denegri, M.; Albertini, A.; Wengler, G.S. \& Parolini, O. (2007). Isolation and characterization of mesenchymal cells from human fetal membranes. Journal of Tissue Engineering and Regenerative Medicine, Vol. 1. No. 4, (July-August 2007), pp. 296-305, ISSN 1932-6254, EISSN 1932-7005

Souza, R.F.; Krishnan, K. \& Spechler, S.J. (2008). Acid bile, and CDX: the ABCs of making Barrett's metaplasia. American Journal Physiology of Gastrointestinal and Liver Physiology, Vol. 295, No. 2, (August 2008), pp. G211-G218, ISSN 0193-1857, EISSN 1522-1547

Souza, R.F. (2010) The molecular basis of carcinogenesis in Barrett's esophagus. Journal of Gastrointestinal Surgery, Vol. 14, No. 6, (June 2010), pp. 937-940, EISSN 1873-4626

Studeny, M.; Marini, F.C.; Dembinski, J.L.; Zompetta, C.; Cabreira-Hansen, M.; Bekele, B.N.; Champlin, R.E. \& Andreeff, M. (2004). Mesenchymal stem cells: potential precursors for tumor stroma and targeted-delivery vehicles for anticancer agents. The Journal of the National Cancer Institute, Vol. 96, No. 21, (November 2004) pp. 1593-603, ISSN 0027-8874, EISSN 1460-2105

Suchi, K.; Fujuwara, H.; Okamura, H.; Umehara, S.; Todo, M.; Furutani, A.; Yoneda, M.; Shiozaki, A.; Kubota, T.; Ichikawa, D.; Okamoto, K. \& Otsuji, E. (2011). Over- 
expression of interleukin-6 suppresses cisplatin-induced cytotoxicity in esophageal squamous cell carcinoma cells. Anticancer Research, Vol. 31, No. 1, (January 2011), pp. 67-75, ISSN 0250-7005, EISSN 1791-7530.

Sun, Z.G.; Huang, S.D.; Zhang, B.R.; Xu, Z.Y.; Liu, X.H.; Gong, D.J. \& Yuan, Y. (2009). [Isolation and identification of cancer stem cells from human esophageal carcinoma]. Zhonghua Yi Xue Za Zhi, Vol. 89, No. 5, (February 2009), pp. 291-295, ISSN 03762491

Szarvas, T.; Becker, M.; von Dorp, F.; Gethmann, C.; Tötsch, M.; Bánkfalvi, A.; Schmid, K.W.; Romics, I.; Rübben, H. \& Ergün, S. (2010). Matrix metalloproteinase-7 as a marker of metastasis and predictor of poor survival in bladder cancer. Cancer Science, Vol. 101, No. 5, (May 2010), pp- 1300-1308, ISSN 1347-9032, EISSN 1349-7006

Takayama, N.; Arima, S.; Haraoka, S.; Kotho, T.; Futami, K. \& Iwashita, A. (2003). Relationship between the expression of adhesion molecules in primary esophageal squamous cell carcinoma and metastatic lymph nodes. Anticancer Research, Vol. 23, No. 6a, (November- December 2003), pp. 4435-4442, ISSN0250-7005, EISSN 17917530

Tallone, T.; Realini, C.; Bohmler, A.; Kornfeld, C.; Vassalli, G.; Moccetti, T.; Bardelli, S. \& Soldati, G. (2011). Adult human adipose tissue contains several types of multipotent cells. Journal of Cardiovascular Translational Research, Vol. 4, No. 2, (April 2011), pp. 200-210, ISSN 1937-5387, EISSN 1937-5395

Tanaka, T.; Ishiguro, H.; Kuwabara, Y.; Kimura, M.; Mitsui, A.; Katada, T.; Shiozaki, M.; Naganawa, Y.; Fujii, T. \& Takeyama, H. (2010). Vascular endothelial growth factor C (VEGF-C) in esophageal cancer correlates with lymph node metastasis and poor patient prognosis. Journal of Experimental \& Clinical Cancer Research, Vol. 29, (June 2010), pp. 83, ISSN 1756- 9966

Tselepis, C.; Perry, I.; Dawson, C.; Hardy, R.; Darnton, S.J.; McConkey, C.; Stuart, R.C.; Wright, N.; Harrison, R. \& Jankowski, J.A. (2002). Tumor necrosis factor-alpha in Barrett's oesophagus: a potential novel mechanism of action. Oncogene, Vol. 21, No. 39, (September 2002), pp. 6071-6081, ISSN 0950-9232, EISSN 1476-5594

Thiery, J.P. (2002). Epithermal-mesenchymal transition in tumor progression. Nature Reviews Cancer, Vol. 2, No. 6, (June 2002), pp. 442-454, ISSN 1474-175X, EISSN 1474-1768

Thomas, M.; Kalita, A.; Labrecque, S.; Pim, D.; Banks, L. \& Matlashewski, G. (1999) Two polymorphic variants of wild-type p53 differ biochemically and biologically. Molecular and Cellular Biology, Vol. 19, No. 2, (February 1999), pp. 1092-1100, ISSN 0270-7306, EISSN 1098-5549

Thompson, S.K.; Sullivan, T.R.; Davies, R. \& Ruszkiewicz, A.R. (2011). Her-2/neu gene amplification in esophageal adenocarcinoma and its influence on survival. The Annals of Surgical Oncology, Vol. 18, No. 7, (July 2011), pp. 2010-2017, ISSN 10689265 and EISSN 1543-4681

Torzewski, M.; Sarbia, M.; Verreet, P.; Bittinger, F.; Dutkowski, P.; Heep, H.; Willers, R. \& Gabbert, H.E. (1997). The prognostic significance of epidermal growth factor receptor in squamous cell carcinomas of the esophagus. Anticancer Research, Vol. 17, No. 5B, (September-October 1997), pp. 3915-3919, ISSN 0250-7005, EISSN 1791-7530 
Vegh, I.; Sotelo, T.; Estenoz, J.; Fontanellas, A.; Navarro, S.; Millán, I. \& Enriquez de Salamanca, R. (2002). Tumor cytosol carcinoembryonic antigen as prognostic parameter in non-small-lung cancer. Tumori, Vol. 88, No. 2, (March-April 2002), pp. 142-146, ISSN 0300-8916

Vegh, I.; De La Cruz, J.; Navarro, S.; Morales, C.; Colina, F.; Abad, A.; De La Calle, A.; Enríquez de Salamanca, R.; Moreno-González, E. (2003). Colorectal cancer relapse: allelic alterations associated with tumour marker over-expression. Oncology, Vol. 65, No. 2, (August 2003), pp. 146-152, ISSN 0030-2414, EISSN 1423-0232

Vegh, I.; De-La-Calle Santiuste, A.; Colina, F.; Bor, L.; Bermejo, C.; Aragón, A.; MoránJimenez, M.J., Gomez-Cámara, A.; Enríquez de Salamanca, R. \& Moreno-González, E. (2007). Relationship between biomarker expression and allelic alteration in esophageal carcinoma. Journal of Gastroenterology and Hepatology, Vol. 22, No. 12, (December 2007), pp. 2303-2309, ISSN 0815-9319, EISSN 1440-1746

von Rahden, B.H.; Kircher, S.; Lazariotou, M.; Reiber, C.; Stuermer, L.; Otto, C.; Germer, C.T. \& Grimm, M. (2011). LgR5 expression and cancer stem cell hypothesis: clue to define the true origin of esophageal adenocarcinomas with and without Barrett's esophagus? Journal of Experimental \& Clinical Cancer Research, Vol. 30, (February 2011), p. 23, ISSN 1756-9966

Waldman, T.; Kinzler, K.W. \& Volgelstein, B. (1995) p21 is necessary for the p53-mediated G1 arrest in human cancer cells. Cancer Research, Vol. 55, No. 22, (November 1995), pp. 5187-5190, ISSN 1538-7445, EISSN 0008-5472

Wang Q, He W, Lu C, Wang Z, Wang J, Giercksky KE, Nesland JM, Suo Z. (2009). Oct3/4 and Sox 2 are significantly associated with an unfavorable clinical outcome in human esophageal squamous cell carcinoma. Anticancer Research, Vol. 29, No. 4, (April 2009), pp. 1233-1241, ISSN 0250-7005, EISSN 1791-7530

Whibley, C.; Pahroah, P.D. \& Hollstein, M. (2009). P53 polymorphisms: cancer implications. Nature Reviews Cancer, Vol. 9, No. 2, (February 2009), pp. 95-107, ISSN 1474-175X, EISSN1474-1768

Wu, T.T.; Watanabe, T.; Heimiller, R.; Zahurak, M.; Forastiere, A.A. \& Hamilton, S.R. (1998). Genetic alterations in Barrett esophagus and adenocarcinoma of the esophagus and esophagogastric junction region. The American Journal of Pathology, Vol. 153, No. 1, (July 1998), pp. 287-294, ISSN 002-9440

Xin, Z.; Wenyu, F. \& Shenhua, X. (2010). Clinicopathologic significance of cytokine levels in esophageal squamous cell carcinoma. Hepatogastroenterology, Vol. 57, No. 104, (November- December 2010), pp. 1416-1422, ISSN 0172-6390

Yamamoto, H.; Adachi, Y.; Itoh, F.; Iku, S.; Kusano, K.; Arimura, Y.; Endo, T.; Hinoda, Y.; Hosokawa, M. \& Imai, K. (1999). Association of matrilysin expression with recurrence and poor prognosis in human esophageal squamous cell carcinoma. Cancer Research, Vol. 59, No. 14, (July 1999), pp. 3313-3316, ISSN 1538-7445 EISSN 0008-5472

Yamashita, K.; Mori, M.; Shiraishi, T.; Shibuta, K. \& Sugimachi, K. (2000). Clinical significance of matrix metalloproteinase-7 expression in esophageal carcinoma. Clinical Cancer Research, Vol. 6, No. 3, (March 2000), pp. 1169-1174, ISSN 1557-3265, EISSN 10780432 
Yamashita, K.; Mori, M.; Kataoka, A.; Inoue, H. \& Sugimachi, K. (2001). The clinical significance of MMP-1 in oesophageal cancinoma. British Journal of Cancer, Vol. 84, No. 2, (January 2001), pp. 276-282, ISSN 0007-0920, EISSN 1532-1827

Yoshizuki, T.; Maruyama, Y.; Sato, H. \& Furukawa, M. (2001). Expression of tissue inhibitor of matrix metalloproteinase-2 and predicts poor prognosis in the tongue squamous cell carcinoma. International Journal of Cancer, Vol. 95, No. 1, (January 2001), pp. 4450, ISSN 1097-0215

Yu, C.; Zhang, X.; Huang, Q.; Klein, M. \& Goyal, R.K. (2007). High-fidelity DNA histograms in neoplastic progression in Barrett's esophagus. Laboratory Investigation, Vol. 87, No. 5, (May 2007), pp. 466-472, ISSN 0023-6837 and EISSN 1530-0307

Zhang, X.; Cheung, R.M.; Komaki, R.; Fang, B. \& Chang, J.Y. (2005). Radiotherapy sensitization by tumor-specific TRAIL gene targeting improves survival of mice bearing human non-small cell lung cancer. Clinical Cancer Research, Vol. 11, No. 18, (September 2005), pp. 6657-6668, ISSN 1557-3265, EISSN 1078-0432

Zhang, H.Y.; Zhang, Q.; Zhang, X.; Yu, C.; Huo, X.; Cheng, E.; Wang, D.H.; Spechler, S.J. \& Souza, R.F. (2011). Cancer- Related inflammation and Barrett's carcinogenesis: interleukin-6 and Stat3 mediate apoptotic resistance in transformed Barrett's cells. American Journal Physiology of Gastrointestinal and Liver Physiology, Vol. 300, No. 3, (March 2011), pp. G454-G460, ISSN 0193-1857, EISSN 1522-1547

Zhang, Z.; Wang, M.; Wu, D.; Wang, M.; Tong, N.; Tian, Y. \& Zhang, Z. (2011). P53 codon 72 polymorphism contributes to breast cancer. World Journal of Gastroenterology, Vol. 120, No. 2, (April 2010), pp. 509-517, ISSN 1007-9327

Zhou, Y.; Li, N.; Zhuang, W.; Liu, G.J.; Wu, T.X.; Yao, X.; Du, L.; Wei, M.L. \& Wu, X.T. (2007). P53 codon 72 polymorphism and gastric cancer: a meta-analysis of the literature. International Journal of Cancer, Vol. 121, No. 7, (October 2007), pp. 14811486, ISSN 0020-7136, EISSN 1097-0215

Zhou, J.H.; Zhang, B.; Kmstine, K.H. \& Zhong, L.O. (2011). Autoantibodies against MMP-7 as a novel diagnostic biomarker in esophageal squamous cell carcinoma. World Journal of Gastroenterology, Vol. 17, No. 10, (March 2011), pp. 1373-1378, ISSN 10079327

Zhou, X., G.R. Huang, and P. Hu. (2011). Over-expression of Oct4 in human esophageal squamous cell carcinoma. Molecules and Cells, [Epub ahead of print] May 2011, ISSN 1016-8478, EISSN 0219-1032 


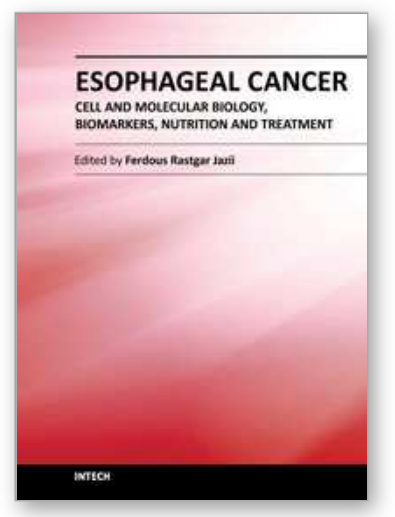

\author{
Esophageal Cancer - Cell and Molecular Biology, Biomarkers, \\ Nutrition and Treatment \\ Edited by Prof. Ferdous Rastgar Jazii
}

ISBN 978-953-51-0223-6

Hard cover, 244 pages

Publisher InTech

Published online 07, March, 2012

Published in print edition March, 2012

Esophageal Cancer illustrates recent achievements and investigations in the esophageal tumorigenesis from different perspectives. Readers find mechanisms involved in esophageal tumorigenesis, cellular, molecular, genetic, epigenetics, and proteomics, their relevance as the novel biomarkers and application in esophageal cancer diagnosis and therapy. The book covers detailed effect of nutritional factors in addition to ethanol metabolic pathway in the inhibition of retinoic acid metabolism and supply. Diagnosis, classification, and treatment of esophageal cancer, application of both surgical and non surgical methods as well as follow up of the disease are described in detail. Moreover readers are endowed with especial features of esophageal cancer such as multiple early stage malignant melanoma and pulmonary edema induced by esophagectomy, the two features that received less attention elsewhere in literature.

\title{
How to reference
}

In order to correctly reference this scholarly work, feel free to copy and paste the following:

Irene Vegh and Ana I. Flores (2012). Biomarkers, Stem Cells and Esophageal Cancer, Esophageal Cancer Cell and Molecular Biology, Biomarkers, Nutrition and Treatment, Prof. Ferdous Rastgar Jazii (Ed.), ISBN: 978953-51-0223-6, InTech, Available from: http://www.intechopen.com/books/esophageal-cancer-cell-andmolecular-biology-biomarkers-nutrition-and-treatment/biomarkers-stem-cells-and-esophageal-cancer

\section{INTECH}

open science | open minds

\author{
InTech Europe \\ University Campus STeP Ri \\ Slavka Krautzeka 83/A \\ 51000 Rijeka, Croatia \\ Phone: +385 (51) 770447 \\ Fax: +385 (51) 686166 \\ www.intechopen.com
}

\author{
InTech China \\ Unit 405, Office Block, Hotel Equatorial Shanghai \\ No.65, Yan An Road (West), Shanghai, 200040, China \\ 中国上海市延安西路65号上海国际贵都大饭店办公楼 405 单元 \\ Phone: +86-21-62489820 \\ Fax: +86-21-62489821
}


(C) 2012 The Author(s). Licensee IntechOpen. This is an open access article distributed under the terms of the Creative Commons Attribution 3.0 License, which permits unrestricted use, distribution, and reproduction in any medium, provided the original work is properly cited. 